\title{
Triassic limestone, turbidites and serpentinite-the Cimmeride orogeny in the Central Pontides
}

\author{
ARAL I. OKAY*†, DEMİR ALTINER $\ddagger$ \& ALİ MURAT KILIÇ $§$ \\ *Istanbul Technical University, Eurasia Institute of Earth Sciences and Department of Geology, Maslak 34469, \\ Istanbul, Turkey \\ $\ddagger$ Middle East Technical University, Department of Geology, Ankara 06531 Turkey \\ §Balıkesir University, Department of Geology, Çağış, Balıkesir 10145, Turkey
}

(Received 3 December 2013; accepted 17 July 2014; first published online 17 September 2014)

\begin{abstract}
The basement of the Central Pontides, and by implication that of Crimea, consists of pre-Permian low-grade metaclastic rocks intruded by latest Permian - Early Carboniferous (305$290 \mathrm{Ma}$ ) granitoids. Further up in the stratigraphic sequence are Triassic limestones, which are now preserved as olistoliths in the deformed Upper Triassic turbidites. New conodont and foraminifera data indicate an Anisian to Carnian (Middle to Late Triassic) age for these hemi-pelagic Hallstatt-type limestones. The siliciclastic turbidites surrounding the Triassic limestone contain the Norian (Late Triassic) bivalve Monotis salinaria; the same species is also found in the Tauric series in Crimea. The Upper Triassic flysch in the Central Pontides is locally underlain by basaltic pillow lavas and includes kilometre-size tectonic slices of serpentinite. Both the flysch and the serpentinite are cut by an undeformed acidic intrusion with an Ar-Ar biotite age of $162 \pm 4 \mathrm{Ma}$ (Callovian-Oxfordian). This indicates that the serpentinite was emplaced into the turbidites before Middle Jurassic time, most probably during latest Triassic or Early Jurassic time, and that the deformation of the Triassic sequence pre-dates the Middle Jurassic. Regional geological data from the circum-Black Sea region, including widespread Upper Triassic flysch, Upper Triassic eclogites and blueschists of oceanic crustal affinity, and apparent absence of a 'Cimmerian continent' between the Cretaceous and Triassic accretionary complexes indicate that the latest Triassic Cimmeride orogeny was accretionary rather than collisional and is probably related to the collision and accretion of an oceanic plateau to the southern active margin of Laurasia.
\end{abstract}

Keywords: Triassic, biostratigraphy, Cimmeride orogeny, Pontides, conodonts, foraminifera.

\section{Introduction}

Scarce Triassic outcrops in the circum-Black Sea region outline three facies belts (Fig. 1). In the west in the Balkans the Triassic sediments were deposited on a continental to shallow marine platform passing to a deep shelf or platform margin at Dobrugea and Istanbul (Gedik, 1975; Muttoni et al. 2000; Seghedi, 2001; Derman, 2002; Bedi et al. 2013). They rest unconformably on the eroded remnants of the Variscan orogen, which include deformed Carboniferous sedimentary rocks and Permo-Carboniferous granitoids. In the north between the Caspian Sea and the Crimea is a Triassic magmatic belt (Nikishin et al. 2001, 2012; Alexandre et al. 2004; Natal'in \& Şengör, 2005). This is known almost solely from subsurface data (Tikhomirov, Chalot-Prat \& Nazarevich, 2004) but is also inferred from abundant Triassic clastic zircons in the Mesozoic sediments in the Pontides (Karslioğlu et al. 2012; Okay et al. 2013; Ustaömer et al. 2014) and in Crimea (A. Nikishin, pers. comm.). South of the magmatic belt and extending westward to the Aegean Sea are strongly deformed, thick turbidite sequences, which

$\dagger$ †uthor for correspondence: okay@itu.edu.tr are associated in the Pontides with Upper Triassic eclogites and blueschists (Fig. 1; Okay, 2000; Nikishin et al. 2001, 2012; Okay \& Göncüoğlu, 2004). These include the Karakaya Complex in western Turkey (Okay \& Göncüoğlu, 2004), the Küre Complex in the Central Pontides (Ustaömer \& Robertson, 1994), the Tauric series in Crimea and the Dizi series in the Caucasus (Adamia et al. 2011; Fig. 1). The significance and origin of this deformation and metamorphism, known as the Cimmeride orogeny, is poorly understood; it is either related to the collision of a 'Cimmerian continent' with the Laurasian margin (Şengör, 1984) or to accretional processes along the active Laurasian margin (Okay, 2000).

Stratigraphic and geochronological data are critical in constraining the origin and timing of the Cimmeride orogeny in the circum-Black Sea region. Here we present new palaeontological and isotopic data on the Triassic series and its basement in the Central Pontides. The data include characterization of a late Variscan metamorphic-plutonic basement, a Middle to Upper Triassic pelagic limestone sequence and pre-Middle Jurassic serpentinites, which occur as tectonic slices in the Upper Triassic turbidites. The Cimmeride deformation is envisaged as an accretionary rather than 


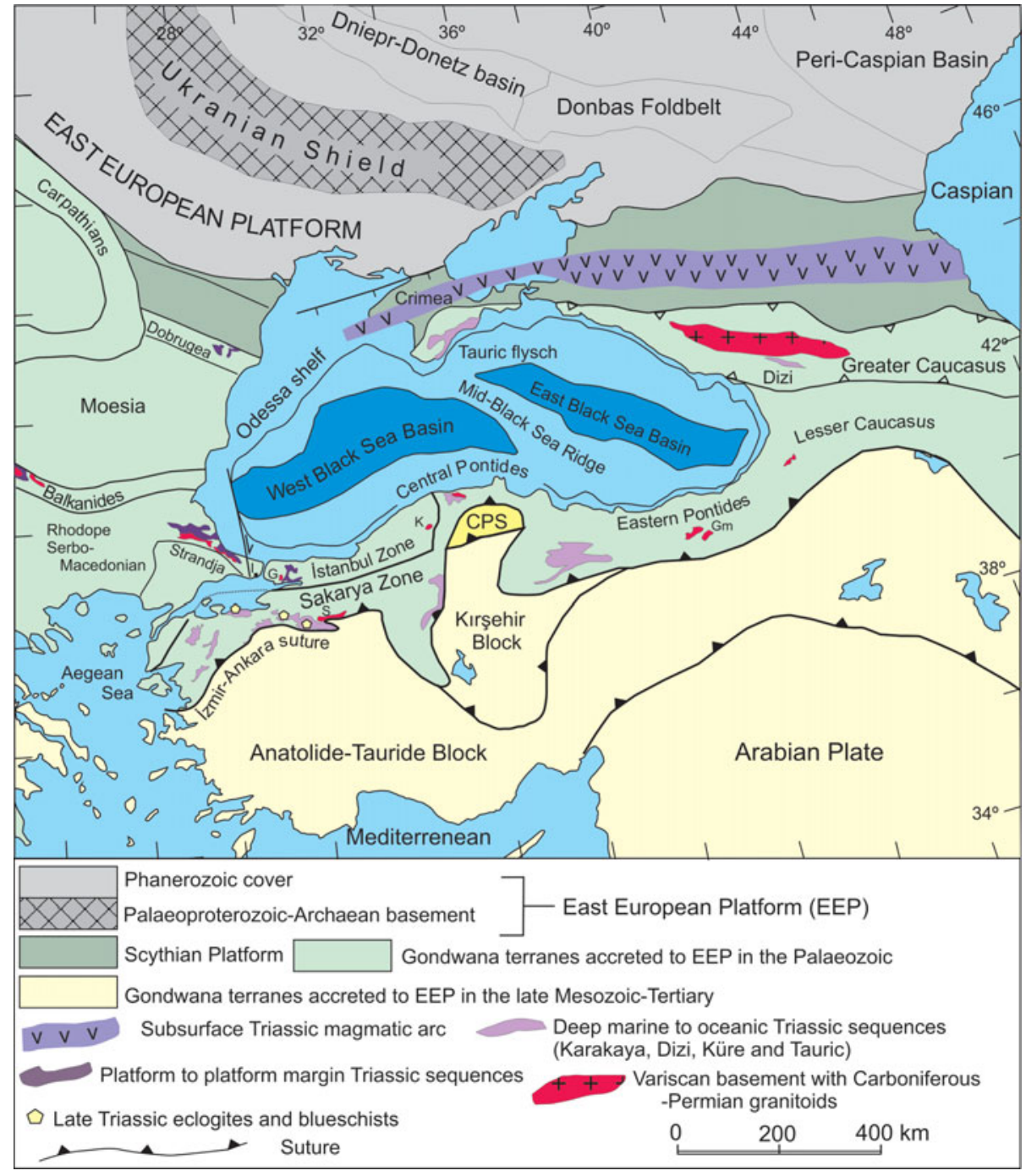

Figure 1. (Colour online) Tectonic map of the circum-Black Sea region showing the outcrops of Triassic strata north of the İzmirAnkara suture (modified from Okay \& Tüysüz, 1999). Abbreviations: CPS - Central Pontide Supercomplex; Permo-Carboniferous granitoids: G - Gebze; Gm - Gümüşhane; I - Istanbul; K - Kürek; S - Söğüt.

collisional orogeny involving latest Triassic attempted subduction and accretion of oceanic edifices.

\section{Geological setting}

The Central Pontides include two Pontic terranes: the Istanbul Zone in the west and the Sakarya Zone in the east (Fig. 1). They share a common Upper Jurassic shallow marine limestone cover in the Central Pontides but show different pre-Jurassic development (Fig. 2). The Istanbul Zone is characterized by a welldeveloped Palaeozoic (Ordovician to Carboniferous) sedimentary sequence, including Carboniferous coal measures (Görür et al. 1997; Dean et al. 2000), which rests on a late Neoproterozoic granitic basement (Chen et al. 2002; Ustaömer, Mundil \& Renne, 2005). The Palaeozoic sequence is intruded by Permian granitoids (Şahin et al. 2009; Okay et al. 2013) and is unconformably overlain by Permo-Triassic red beds and by the Middle Jurassic lacustrine limestone and shale (Fig. 2).

The crystalline basement of the Sakarya Zone in the Central Pontides is represented by poorly exposed Permo-Carboniferous granitoids and metamorphic rocks close to the Black Sea margin (Fig. 1; Nzegge et al. 2006; O. M. Nzegge, unpub. Ph.D. thesis, Univ. Tübingen, 2008). The large area of metamorphic rocks in the southern part of the Central Pontides, the Central Pontide Supercomplex (Figs 1, 3), which is shown as Triassic and older basement on the geological maps and in publications (e.g. Y1lmaz \& Şengör, 1985; Tüysüz, 1990; Ustaömer \& Robertson, 1994, 1999; Yılmaz et al. 1997; Yiğitbaş, Elmas \& Yılmaz, 1999; Uğuz, Sevın \& Duru, 2002), has recently been shown to be of Jurassic and Cretaceous age (Okay et al. 2006, 2013).

The Permo-Carboniferous granitoids in the Central Pontides are overlain in the south by the Upper Triassic turbidites, which constitute part of an orogenic Triassic volcano-sedimentary unit called the Küre Complex (Ustaömer \& Robertson, 1994). The Upper Triassic turbidites also crop out in the southern Crimea as the Tauric series (Zonenshain, Kuzmin \& Natapov, 1990). The Küre Complex and the Tauric series are intruded by Middle Jurassic shallow level intrusions and are 


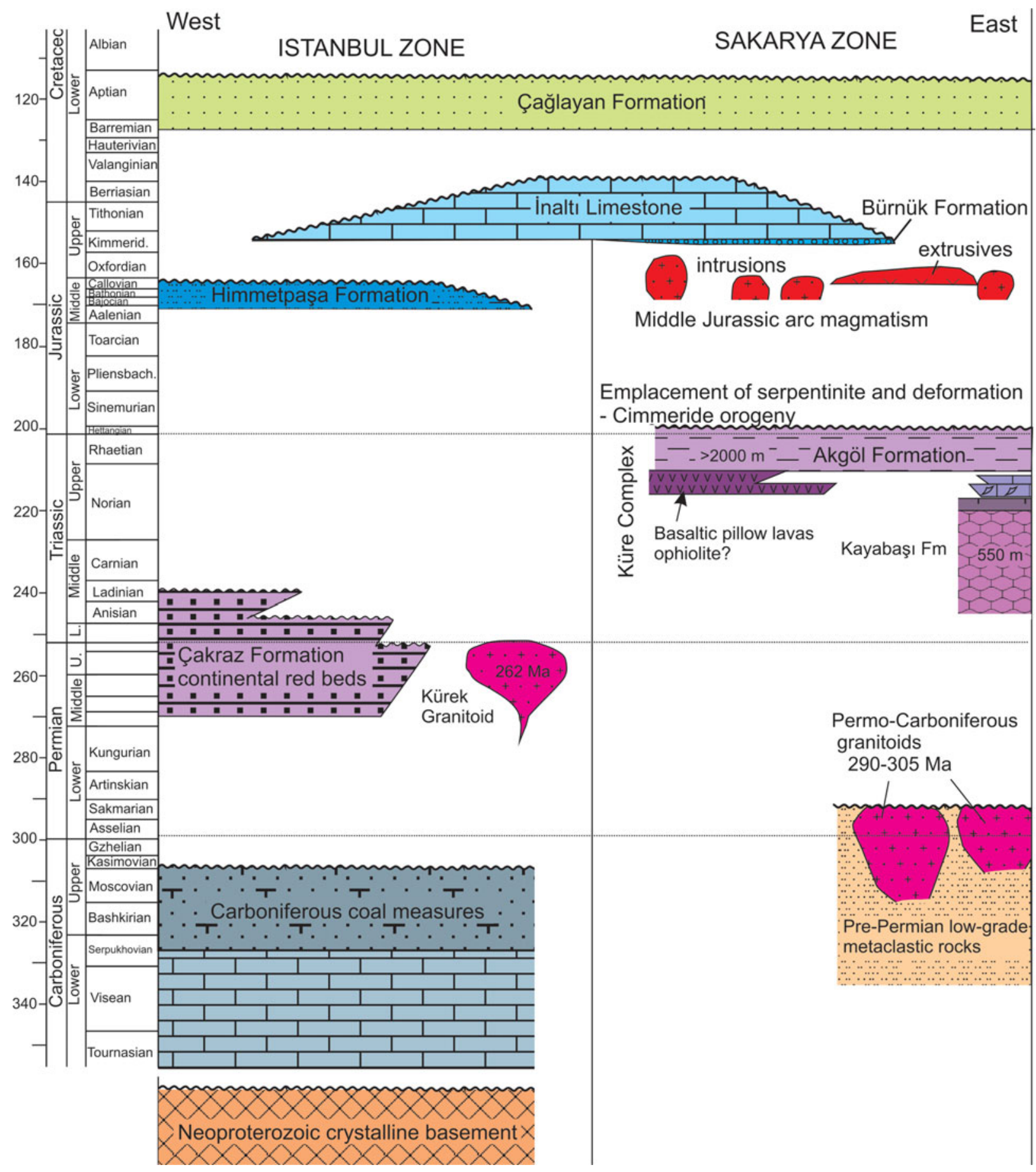

Figure 2. (Colour online) Stratigraphic section of the Istanbul and Sakarya zones in the Central Pontides (modified from Okay et al. 2014). The geological time scale is after Cohen et al. (2013).

unconformably overlain by Upper Jurassic continental clastic rocks and limestones (Fig. 2). For this study we worked in detail in the Central Pontides and made a geological field trip to Crimea.

\section{The late Variscan basement}

Palaeozoic low-grade metasedimentary rocks intruded by Permian and Carboniferous granitoids constitute the basement of the Central Pontides. The basement crops out poorly in the densely vegetated coastal region south of Inebolu and Abana (Fig. 3). The metasedi- mentary rocks consist of black to brown slates to phyllites interbedded with metasiltstone and fine-grained metasandstone (Boztuğ \& Yılmaz, 1983). A serpentinite lens, $c .100 \mathrm{~m}$ thick occurs within the slates close to the Late Carboniferous granitoid (Fig. 4, UTM coordinates 36T 0573450-4633030) and has undergone contact metamorphism, which indicates a pre-Permian age for the serpentinite. Boztug \& Yılmaz (1983) also described from further east a serpentinite lens in the contact metamorphic aureole of the Late Carboniferous granitoid. The metaclastic rocks are lithologically similar to the Upper Triassic turbidites, and have 


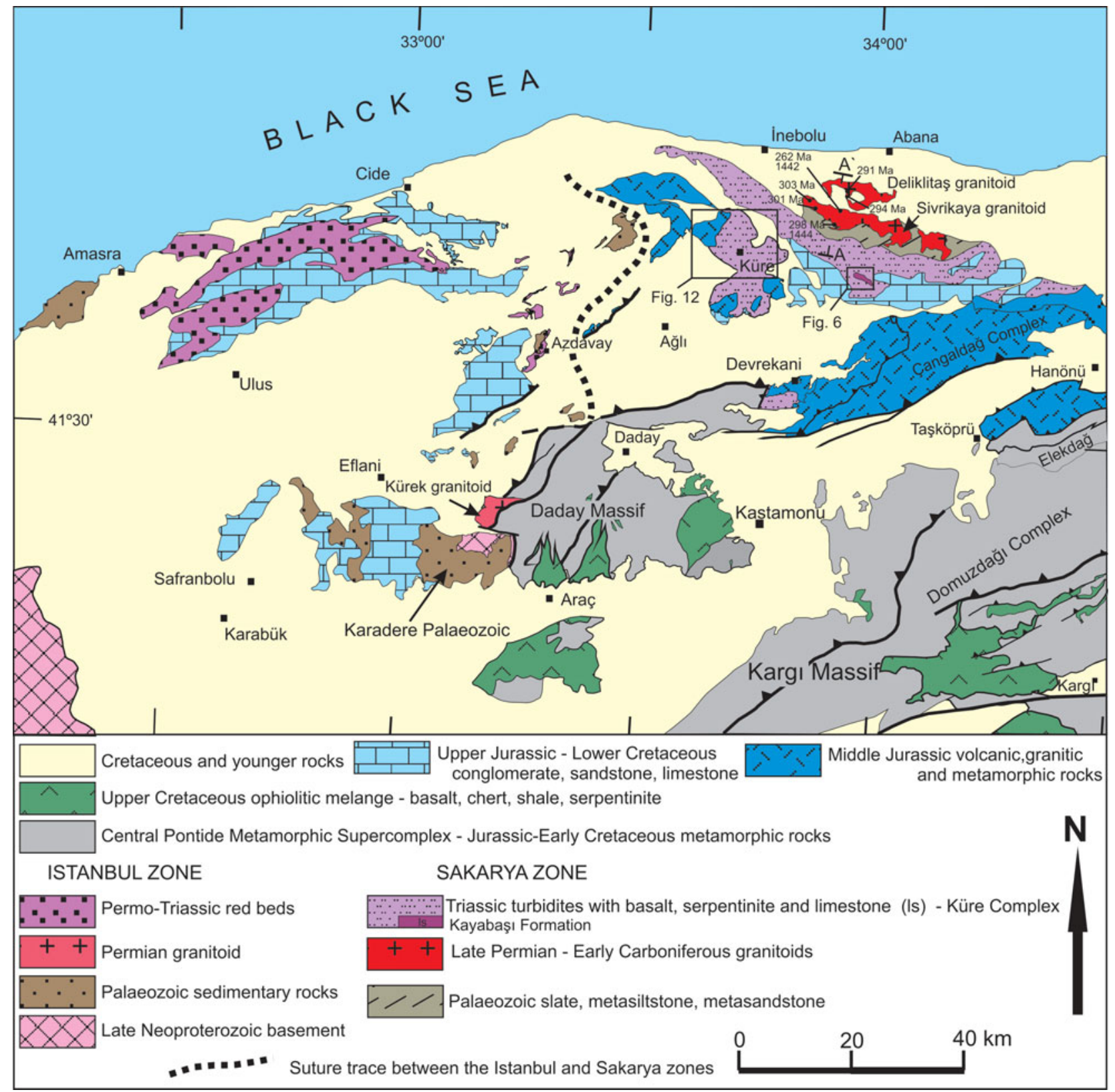

Figure 3. (Colour online) Geological map of the Central Pontides with outcrops of pre-Cretaceous units and Central Pontide Metamorphic Supercomplex (based on Aydın et al. 1995; Aksay et al. 2002; Uğuz, Sevın \& Duru, 2002; Okay et al. 2013).

previously been mapped as such (Boztuğ \& Y1lmaz, 1983); however, they have undergone a lowgreenschist-facies regional metamorphism, and a penetrative cleavage is well developed even in sandstones. The region is later deformed by thrusting and folding and is cut by normal faulting, all probably of Eocene and younger age (Fig. 4).

The metasedimentary rocks are intruded by granitoids leading to the generation of hornfels in the contact aureole. Previously, these granitoids were considered Middle Jurassic in age (Boztuğ \& Yılmaz, 1983; Boztuğ et al. 1984, 1995). However, isotopic dating by Nzegge et al. (2006) produced latest Carboniferous and Early Permian ages (Table 1). The Variscan granitoids comprise the Deliklitaş granitoid in the north and the Sivrikaya Granitoid in the south; they may be connected under the Cretaceous cover (Figs 3,4). Close to the northern margin of the Sivrikaya Granitoid, there are numerous of $1-10 \mathrm{~m}$ thick enclaves of gneissic micaschists with the mineral assemblage of quartz $+\mathrm{K}$ feldspar + muscovite + biotite + sillimanite.

In terms of mineral assemblage, the Deliklitas and Sivrikaya intrusions range from hornblende-biotite granodiorite to two-mica granite (Boztuğ \& Yılmaz, 1983; Nzegge et al. 2006). They are peraluminous, calc-alkaline and high-K in composition (Nzegge et al. 2006). Geochemical features of the granitoids, including their $\varepsilon \mathrm{Nd}_{(t)}, \delta^{18} \mathrm{O}$ values and $\mathrm{Sr}_{(\mathrm{i})}$ ratios, suggest derivation by dehydration melting of metapelitic and mafic crust (Nzegge et al. 2006). This is also supported by the presence of primary muscovite and enclaves of high-temperature metamorphic rocks in the 


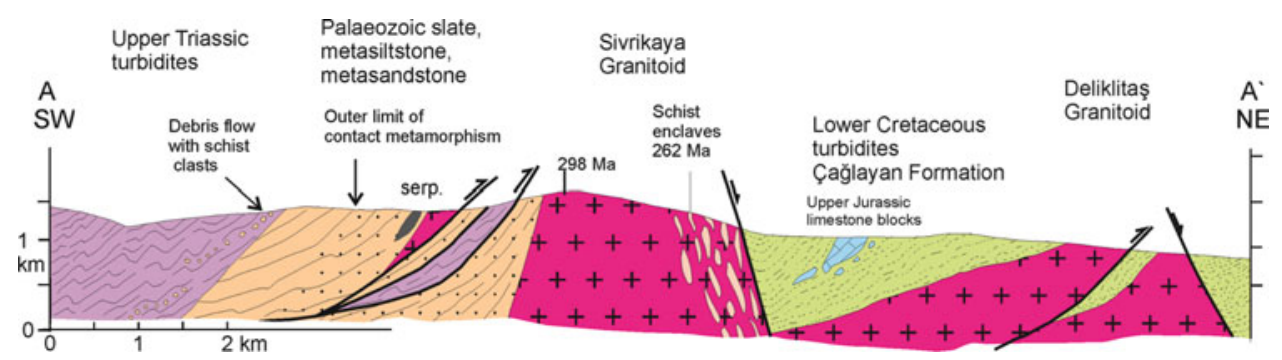

Figure 4. (Colour online) Geological cross-section from the northern part of the Central Pontides showing the relationship between the Variscan basement and the overlying units. For location of the section see Figure 3.

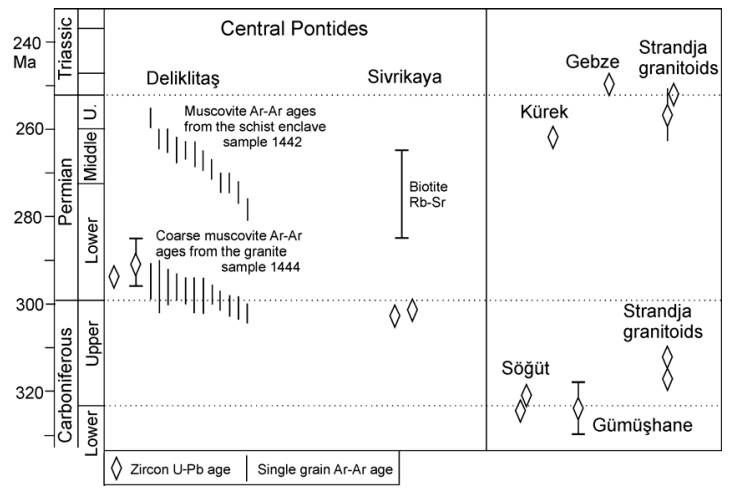

Figure 5. Isotopic age data from the Permo-Carboniferous granitoids in the Pontides (Y1lmaz, 1975; Nzegge et al. 2006; O. M. Nzegge, unpub. Ph.D. thesis, Univ. Tübingen, 2008; Okay et al. 2001, 2013; Şahin et al. 2009; Sunal et al. 2006; Topuz et al. 2010; Ustaömer, Ustaömer \& Robertson, 2012; this study).

Deliklitaş granitoid. On the tectonic discrimination diagrams most samples plot in the field of volcanic arc granitoids (Nzegge et al. 2006). Their peraluminous nature, high $\mathrm{K}$ and $\mathrm{Sr}$ contents, high $\mathrm{Rb} / \mathrm{Sr}$ values and initial $\mathrm{Sr}$ ratios point to crustal melting and suggest an episode of crustal thickening.

$\mathrm{U}-\mathrm{Pb}$ magmatic zircon ages from two samples of the Sivrikaya Granitoid are $303 \pm 2 \mathrm{Ma}$ and $301 \pm 2 \mathrm{Ma}$ (latest Carboniferous) (Nzegge et al. 2006; O. M. Nzegge, unpub. Ph.D. thesis, Univ. Tübingen, 2008; Table 1). During this study, coarse muscovites from a sample of the Sivrikaya Granitoid were dated using the $\mathrm{Ar}-\mathrm{Ar}$ laser probe at the Open University in the UK. The location of sample 1444 is shown in Figure 3. The mineral separation and analytical methods are explained in the online Supplementary Material available at http://journals. cambridge.org/geo; the analytical data are given in Table $\mathrm{S} 1$ in the online Supplementary Material available at http://journals.cambridge.org/geo. Twelve grains of muscovite produced a mean age of $298 \pm 2 \mathrm{Ma}$ (Fig. 5; Table 1), which is similar to the zircon $\mathrm{U}-\mathrm{Pb}$ ages. The muscovites in the sample are $4-10 \mathrm{~mm}$ long, and the blocking temperature for such coarse-grained muscovites may reach $600-650{ }^{\circ} \mathrm{C}$ (Cliff, 1985). To constrain the cooling history of the Sivrikaya Granitoid, we used the $\mathrm{Ar}-\mathrm{Ar}$ method to date small muscovites (c. $0.4 \mathrm{~mm}$ long) from a micaschist enclave (sample
1442 in Fig. 3; Table 2). The micaschist consists of quartz + muscovite + biotite + sillimanite. Eleven muscovite grains gave ages ranging from $279 \mathrm{Ma}$ to $262 \mathrm{Ma}$ with an average of $267 \pm 6 \mathrm{Ma}$ (Fig. 5; Table 1; Table S1 in the online Supplementary Material available at http://journals.cambridge.org/geo), suggesting a long period of cooling. O. M. Nzegge (unpub. Ph.D. thesis, Univ. Tübingen, 2008) also obtained a biotite whole-rock $\mathrm{Rb}-\mathrm{Sr}$ age of $275 \pm 10 \mathrm{Ma}$ from the Sivrikaya Granitoid. The zircon $\mathrm{U}-\mathrm{Pb}$, muscovite $\mathrm{Ar}-$ $\mathrm{Ar}$ and biotite $\mathrm{Rb}-\mathrm{Sr}$ ages indicate that the Sivrikaya Granitoid crystallized in latest Carboniferous time (c. $302 \mathrm{Ma}$ ) and underwent a slow cooling during Permian time.

The Deliklitaş Granitoid is slightly younger than the Sivrikaya Granitoid; two samples from the granitoid produced Early Permian zircon U-Pb ages of $294 \pm 1 \mathrm{Ma}$ and $291 \pm 5 \mathrm{Ma}$ (Nzegge et al. 2006; O. M. Nzegge, unpub. Ph.D. thesis, Univ. Tübingen, 2008; Table 1). The Sivrikaya and Deliklitaş granitoids crystallized at around the Permian-Carboniferous boundary, and this was followed by a prolonged cooling. The magmatism appears to have changed from slightly metaluminous in latest Carboniferous time to peraluminous S-type in Early Permian time (Nzegge et al. 2006). Granitoids of Early Carboniferous to latest Permian age occur over a wide area in the Pontides (Figs. 1, 5; Table 1) and are also described from the core of the Greater Caucasus (Hanel, Gurbanov, \& Lippolt, 1992; Somin, 2011). They constitute a link between the Variscan belt of central Europe and the Urals.

The Palaeozoic metasedimentary rocks are overlain in the south by the Upper Triassic turbidites (Figs. 3, 4). No clear contact can be observed in the field; however, the presence of debris flows with metamorphic rock clasts in the Upper Triassic turbidites just above the contact suggests the presence of an unconformity (Fig. 4).

\section{The Küre Complex}

The Küre Complex consists of a thick siliciclastic Upper Triassic turbidite sequence, called the Akgöl Formation, associated with basalt, gabbro and serpentinite (Ustaömer \& Robertson, 1994). Economic massive sulphide deposits occur along the shale-basalt contacts. 
Table 1. Selected isotopic ages from the Central Pontides

\begin{tabular}{|c|c|c|c|c|c|c|c|c|c|}
\hline Sample & UTM coordinates & Formation & Rock type & Method & Dated mineral & Mean age (Ma) & Error \pm & No. of analysis & Ref. \\
\hline SG-116 & & Sivrikaya Granitoid & tonalite & $\mathrm{U}-\mathrm{Pb}$ isotope dilution & zircon & 303.0 & 0.5 & 3 fractions & a \\
\hline SG-132 & & Sivrikaya Granitoid & granodiorite & $\mathrm{U}-\mathrm{Pb}$ isotope dilution & zircon & 301.1 & 1.4 & 3 fractions & $\mathrm{a}$ \\
\hline 1444 & 36T $0541483-4597700$ & Sivrikaya Granitoid & granite & $\mathrm{Ar}-\mathrm{Ar}$ single grain & muscovite & 298.0 & 2.0 & 10 grains & $\mathrm{b}$ \\
\hline 1442 & $36 \mathrm{~T} 0541513-4597409$ & Sivrikaya Granitoid & micaschist enclave & $\mathrm{Ar}-\mathrm{Ar}$ single grain & muscovite & 267.0 & 6.0 & 11 grains & $\mathrm{b}$ \\
\hline DLG-114 & & Deliklitaş Granitoid & monzogranite & $\mathrm{U}-\mathrm{Pb}$ isotope dilution & zircon & 294.3 & 1.1 & 4 fractions & $\mathrm{a}$ \\
\hline DLG-83 & & Deliklitas Granitoid & monzogranite & $\mathrm{U}-\mathrm{Pb}$ isotope dilution & zircon & 291.0 & 5.0 & 5 fractions & $\mathrm{a}$ \\
\hline 1723 & 36T $0524926-4577225$ & Karaman Granitoid & granitoid & $\mathrm{Ar}-\mathrm{Ar}$ single grain & biotite & 162.0 & 4.0 & 10 grains & $\mathrm{b}, \mathrm{c}$ \\
\hline 2478 & $36 \mathrm{~T} 0519320-4582570$ & Kürek Granitoid & diorite & $\mathrm{U}-\mathrm{Pb}$ laser ICP-MS & zircon & 261.9 & 2.8 & 13 grains & d \\
\hline
\end{tabular}

a - Nzegge et al. 2006; O. M. Nzegge, unpub. Ph.D. thesis, Univ. Tübingen, 2008; b - this study; c - Okay et al. 2014; d - Okay et al. 2013.

The UTM coordinates are from the European 1979 grid, which is closely compatible with the 1:25000 scale topographic maps of Turkey.

Table 2. Ar-Ar data from the Middle Jurassic porphyry intruding into serpentinite

\begin{tabular}{|c|c|c|c|c|c|c|c|c|c|c|c|c|c|c|c|c|c|c|c|c|c|c|c|}
\hline \multicolumn{24}{|c|}{ Biotites from dacite-porphyry of the Karaman pluton, sample 1723} \\
\hline \multicolumn{24}{|c|}{ UTM coordinates $36 \mathrm{~T}$ 0554646-4631215 } \\
\hline grains & ${ }^{40} \mathrm{Ar}$ & $+/-$ & ${ }^{39} \mathrm{Ar}$ & $+/-$ & ${ }^{38} \mathrm{Ar}$ & $+/-$ & ${ }^{37} \mathrm{Ar}$ & $+/-$ & ${ }^{36} \mathrm{Ar}$ & $+/-$ & ${ }^{40} \mathrm{Ar} *{ }^{39} \mathrm{Ar}$ & $+/-$ & Age (Ma) & $+/-$ & +/- (no J error) & $39 / 40$ & $+/-$ & $36 / 40$ & $+/-$ & $37 / 39$ & $+/-$ & $38 / 39$ & $+/-$ \\
\hline 1 & 0.472036821 & 0.0033116 & 0.041170318 & 0.0003422 & 0.00060537 & $4.33 \mathrm{E}-05$ & 0.0069663 & 0.0001519 & 0.0002324 & $2.26 \mathrm{E}-05$ & 9.797128795 & 0.198455 & 166 & 3 & 3.218546166 & 0.0872184 & 0.00094862 & 0.0004924 & $4.80 \mathrm{E}-05$ & 0.1692069 & 0.0039491 & 0.0147039 & 0.001057817 \\
\hline 2 & 0.869879945 & 0.0035099 & 0.075085834 & 0.0006517 & 0.0012595 & $6.29 \mathrm{E}-05$ & 0.01144851 & 0.000152 & 0.0005113 & $4.14 \mathrm{E}-05$ & 9.573110912 & 0.1886169 & 163 & 3 & 3.065164447 & 0.0863175 & 0.00082616 & 0.0005877 & $4.76 \mathrm{E}-05$ & 0.1524723 & 0.0024181 & 0.0167741 & 0.000850707 \\
\hline 3 & 0.375695514 & 0.0029463 & 0.03084543 & 0.0003731 & 0.00060537 & $5.30 \mathrm{E}-05$ & 0.00781208 & 0.000152 & 0.0003122 & $3.18 \mathrm{E}-05$ & 9.188908383 & 0.33792069 & 156 & 6 & 5.510532697 & 0.0821022 & 0.00118353 & 0.000831 & $8.49 \mathrm{E}-05$ & 0.2532653 & 0.0058034 & 0.0196258 & 0.001735333 \\
\hline 4 & 0.50947467 & 0.0026854 & 0.043110351 & 0.0004968 & 0.00072802 & $4.33 \mathrm{E}-05$ & 0.01143214 & 0.0001521 & 0.0003113 & $3.18 \mathrm{E}-05$ & 9.684413433 & 0.25258953 & 164 & 4 & 4.100655816 & 0.0846173 & 0.00107237 & 0.0006109 & $6.25 \mathrm{E}-05$ & 0.2651832 & 0.0046675 & 0.0168873 & 0.001022149 \\
\hline 5 & 0.564965457 & 0.0024976 & 0.041453459 & 0.0005691 & 0.00065647 & $5.30 \mathrm{E}-05$ & 0.01658793 & 0.0001522 & 0.0005899 & $3.18 \mathrm{E}-05$ & 9.423893692 & 0.26777225 & 160 & 4 & 4.35735434 & 0.0733734 & 0.00105824 & 0.0010441 & $5.64 \mathrm{E}-05$ & 0.4001579 & 0.0066071 & 0.0158363 & 0.001297464 \\
\hline 6 & 0.38280888 & 0.0024142 & 0.028070976 & 0.0003937 & 0.00058492 & $6.29 \mathrm{E}-05$ & 0.03104991 & 0.0001522 & 0.0004161 & $3.18 \mathrm{E}-05$ & 9.257387182 & 0.36905397 & 158 & 6 & 6.014505821 & 0.073329 & 0.00112765 & 0.0010869 & $8.33 \mathrm{E}-05$ & 1.1061215 & 0.016434 & 0.0208373 & 0.002260919 \\
\hline 7 & 0.442439163 & 0.002143 & 0.03325948 & 0.0008686 & 0.00061559 & $6.29 \mathrm{E}-05$ & 0.01441242 & 0.0001523 & 0.0003905 & $3.18 \mathrm{E}-05$ & 9.833477183 & 0.38709179 & 167 & 6 & 6.275809826 & 0.075173 & 0.0019966 & 0.0008825 & $7.20 \mathrm{E}-05$ & 0.4333326 & 0.0122082 & 0.0185086 & 0.001952963 \\
\hline 8 & 0.168385994 & 0.0014654 & 0.012430615 & 0.000301 & 0.00025786 & $5.30 \mathrm{E}-05$ & 0.00537932 & 0.0001524 & 0.0001729 & $2.26 \mathrm{E}-05$ & 9.436846672 & 0.59534184 & 160 & 10 & 9.686636019 & 0.0738221 & 0.00189949 & 0.0010266 & 0.00013444 & 0.4327474 & 0.0161274 & 0.0207437 & 0.004295063 \\
\hline 9 & 0.932827755 & 0.0030611 & 0.065860794 & 0.0007136 & 0.00118795 & 0.0001032 & 0.02157562 & 0.0001525 & 0.0010786 & $3.18 \mathrm{E}-05$ & 9.324376857 & 0.18084396 & 159 & 3 & 2.945447871 & 0.0706034 & 0.00079934 & 0.0011562 & 3.43E-05 & 0.3275943 & 0.0042378 & 0.0180374 & 0.001578808 \\
\hline 10 & 0.801447333 & 0.0021012 & 0.058842641 & 0.0005381 & 0.00103464 & $6.29 \mathrm{E}-05$ & 0.02296087 & 0.0001525 & 0.0008282 & $4.14 \mathrm{E}-05$ & 9.46106257 & 0.2277968 & 161 & 4 & 3.705606988 & 0.0734205 & 0.00069849 & 0.0010334 & $5.17 \mathrm{E}-05$ & 0.3902079 & 0.0044104 & 0.0175832 & 0.001081547 \\
\hline
\end{tabular}


In the flysch there is also a large outcrop of Triassic limestone, which was studied in detail.

\section{4.a. Middle-Upper Triassic limestone}

In the Central Pontides the Permo-Carboniferous granitoids are unconformably overlain by the Upper Triassic turbidites indicating a period of uplift and erosion before Late Triassic time. The earlier Triassic sequences are found as sedimentary blocks in the Upper Triassic flysch. The largest block, known since Blumenthal documented it in 1948, crops out northeast of Devrekani (Fig. 3). Önder (1988) named the limestones the Kayabaş1 Formation, and ascribed a 'topmost Middle Triassic - Late Triassic' age based on conodonts. The Kayabaş1 Formation is of palaeogeographic and stratigraphic importance as it constitutes the only coherent marine limestone Triassic section in the Pontides with the exception of the Triassic in the western part of the Istanbul Zone. The Kayabaş1 Formation was mapped in detail, several stratigraphic sections were measured and over 80 samples were collected for foraminifera and conodonts (Fig. 6).

The Kayabaş1 Formation forms a c. $550 \mathrm{~m}$ thick and $4 \mathrm{~km}$ long block in the turbidites of the Akgöl Formation, cropping out along a NW-SE-trending ridge (Fig. 7a). The bedding in the limestone is difficult to recognize; when it is recognized it dips steeply (60$70^{\circ}$ ) south to southwest forming an inverted sequence (Fig. 6). The limestone is bounded in the northeast by a normal fault, and is stratigraphically overlain in the south by the turbidites of the Akgöl Formation. The Akgöl Formation above the Kayabaşı Formation includes small blocks of Triassic limestone (Fig. 7b).

The Kayabaşı Formation is subdivided into three members (Fig. 8):

(a) The limestone breccia member (Anisian). It constitutes the basal $200 \mathrm{~m}$ of the Kayabaş1 Formation and is best observed on the ridge east of Çal village (Fig. 6). It consists of limestone breccia, with 1 to $10 \mathrm{~cm}$ sized light grey carbonate clasts set in a red micritic or sandy matrix (Fig. 7c). The limestone breccias are locally separated by thinly bedded micritic limestone beds. Textures showing a transition from bedded limestone to breccia, and the preservation of ghost bedding in some of the breccias (Fig. 7d) suggest that brecciation occurred largely in situ without significant transport.

A sample from the thinly bedded micritic limestones from the lower part of the succession (sample 1874) contains foraminifera characteristic of the Anisian: $M e$ androspira pusilla, Meandrospira dinarica, Endoteba controversa, Nodasoria elabugae and Trochammina sp. (Fig. 9). Samples from further up in the sequence contain Anisian conodonts: Neogondolella regalis (sample 1866), Gladigondolella timorensis budurovi (juvenile) and Neogondolella regalis (sample 1868) (Fig. 10). These beds also contain Anisian foraminifera: Arenovidalina amylovoluta, Arenovidalina chialingchiangensis, Opthalmidium? ubeyliense (sample 1867) and Arenovidalina amylovoluta (sample 1868; Fig. 9). The palaeontological data indicate an Anisian age for the limestone breccia member.

(b) The Hallstatt-type micritic limestone member (Anisian to Carnian). This includes pinkish, ammonoid-bearing pelagic limestones, which form the middle part of the Kayabaşı Formation and is $c .300 \mathrm{~m}$ thick. It is best observed on the Kayabaş1 ridge east of Mermerli Stream (Fig. 6). The basal part of the Hallstatt member consists of dark grey micritic limestones. These pass upwards into Hallstatt-type pinkish, slightly nodular, micritic limestones locally with intercalations of grey medium-bedded calc-arenite. Ammonites of the Arcestidae group, characteristic of the Middle-Upper Triassic, occur in the pink limestones.

A $220 \mathrm{~m}$ thick section was measured in the Hallstatt member. Anisian conodonts (Paragondolella bulgarica and Neogondolella regalis, samples 1883 and 1884), the Anisian-Ladinian conodont Neogondolella constricta and Anisian-Ladinian foraminifera Arenovidalina chialingchiangensis, Arenovidalina chialingchiangensis rhombea, Arenovidalina amylovoluta, Arenovidalina spp., Hoyanella sp., Eoophthalmidium tricki, Ophthalmidium sp. and 'Nodasaria' skyphica (sample 1886) occur in the basal massive grey micrites. A sample taken $20 \mathrm{~m}$ above sample 1886 contains Ladinian conodonts: Gladigondolella tethydis and Metapolygnathus excelsa (sample 1888). Ladinian to Carnian conodonts (Gladigondolella tethydis, Metapolygnathus Gr. excelsus-inclinatus, M. inclinatus, $M$. cf. fueloepi and M. carpathicus, sample 1889) and foraminifera (Turriglomina mesotriasica and Turriglomina scandonei, sample 1889) and Carnian foraminifera (Gsolbergella spiriloculiformis, Ophthalmidium sp., Cucurbita sp., Endoteba kuepperi, Endoteba obturata, Endotebanella sp. (sample 1890) associated with Tubiphytes obscurus, and Baccanella floriformis) were determined in the succeeding samples. A sample taken from the top part of the Hallstatt limestone member comprises Carnian conodonts: Gladigondolella tethydis and Metapolygnathus polygnathiformis (sample 1892), and Gladigondolella malayensis and M. tadpole (sample 1895). The palaeontological data indicate an Anisian to Carnian age for the Hallstatt member.

(c) The black limestone-shale member. Black limestone and interbedded shale occur in the northernmost part of the limestone ridge and constitute stratigraphically the upper member of the Kayabaş1 Formation. Its contact with the Hallstatt member is not exposed in the field. The member consists of mediumbedded black limestone with abundant thin-shelled bivalve fragments intercalated with thin black shale beds. Limestone samples from this member contain Lagenidtype foraminifera and thin-shelled bivalves but no age diagnostic fossils.

The palaeontological data indicate an Anisian to Carnian age for the Kayabaşı Formation. In terms of facies and age, it can be compared with the Triassic sequence in Dobrugea (Seghedi, 2001) and to a lesser degree with the Triassic in the western part of the Istanbul Zone (Yurttaş-Özdemir, 1971; Assereto, 1972); 


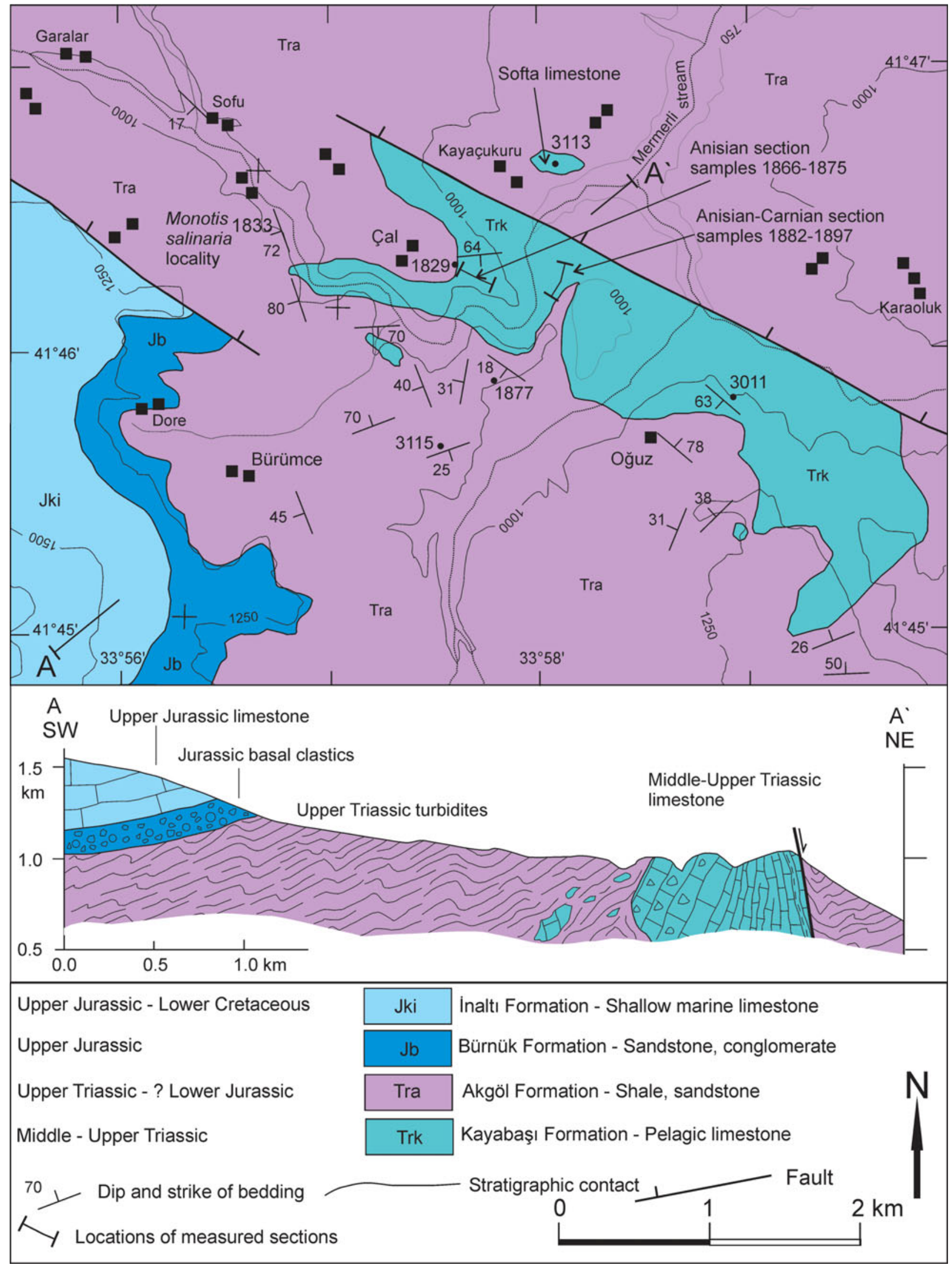

Figure 6. (Colour online) Geological map and cross-section of the Triassic limestones northeast of Devrekani. For location see Figure 3. 

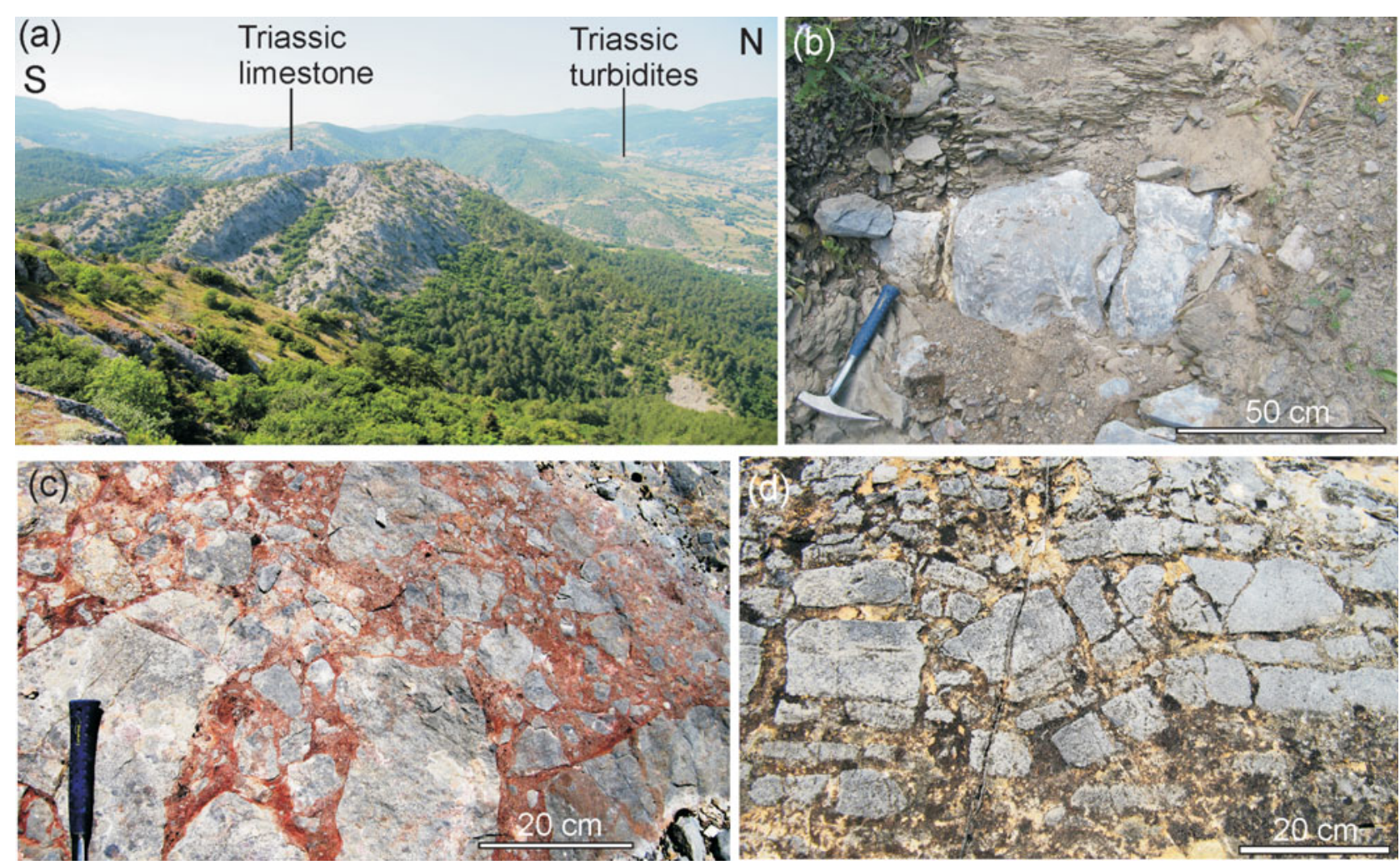

Figure 7. (Colour online) Field photographs from the Triassic limestone in the Central Pontides. (a) The Triassic limestone ridge looking towards the west. The low-lying ground on the right (north) consists of Upper Triassic turbidites. (b) Triassic limestone clast in the Upper Triassic sandstone (locality 1877). (c) Limestone breccia-micritic limestone clasts in a red sandy-carbonate matrix (locality 1870). (d) Limestone breccia. The limestone beds are boudinaged but the continuity of the bedding suggests in situ brecciation with minimum transport (locality 1872). For locations see Figure 6.

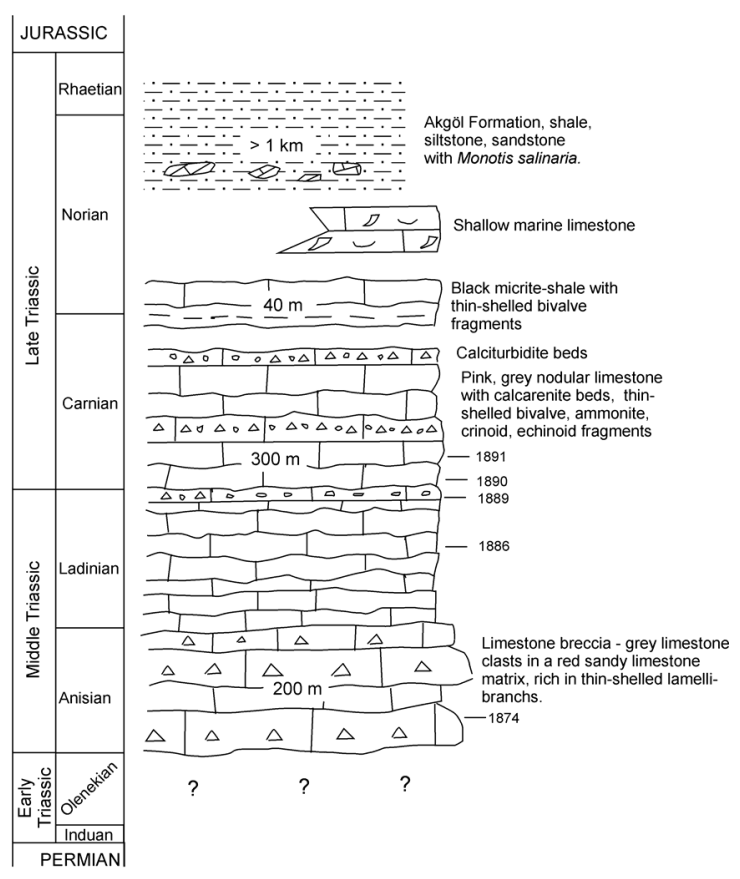

Figure 8. Composite stratigraphic section of the Kayabaşı Formation and the overlying turbidites of the Akgöl Formation. Approximate positions of some important biostratigraphic samples are indicated.

however, the conodont fauna in the Istanbul-Gebze region is quite different (Gedik, 1975; A. M. Kılı̨̧, unpub. Ph.D. thesis, Cumhuriyet Univ., 2004).
Sandstone beds overlying the Kayabaş1 Formation contain debris flow horizons with clasts of Triassic limestone (Fig. 7b). The following lowermiddle Anisian foraminifera were determined in one of the limestone clasts: Meandrospira dinarica, Meandrospira pusilla, Pilammina sp., Endoteba controversa, Planiinvoluta? mesotriasica and Trochammina almtalensis (sample 3115E in Fig. 6). Similar Anisian limestone clasts are described by Kozur et al. (2000) from a debris flow in the Akgöl Formation between İnebolu and Küre.

The large limestone outcrop of the Kayabaşı Formation is surrounded by the sandstones and shales of the Akgöl Formation. This observation, the irregular contacts between these two units (Fig. 6) and the presence of Triassic limestone clasts in the surrounding sandstones (Fig. 7b) indicate that the Triassic limestone forms a large slide block in the turbidites. The in situ brecciation observed in the basal parts of the Kayabaş1 Formation (Fig. 7d) most likely occurred during sliding of the block into the basin.

A different type of limestone block occurs in the Upper Triassic turbidites a few hundred metres north of the Kayabaş1 Formation close to the village of Softa (Fig. 6; Y1lmaz \& Boztuğ, 1987). It consists of $c$. $20 \mathrm{~m}$ thick, thickly bedded to massive, bluish grey, bioclastic limestone with abundant brachiopods, lamellibranchs, coral, algae, sponge spicules, bryozoa and echinoid spine fragments, deposited probably in a 


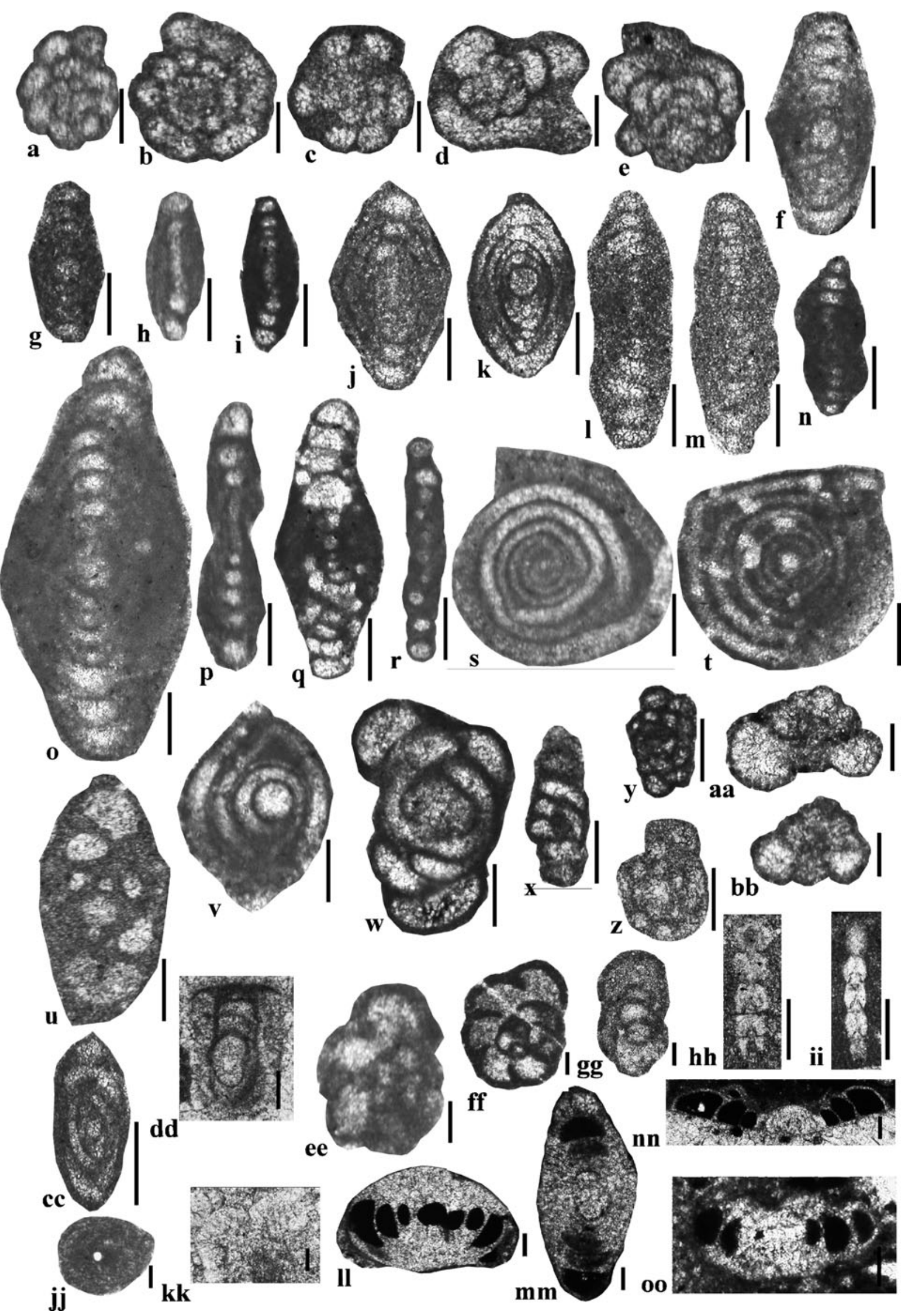

Figure 9. Photomicrographs of foraminifera from the Kayabaş1 Formation. For location of the specimens see Figure 6. (a) Meandrospira pusilla (Ho), sample 3115E. (b, c) Meandrospira dinarica Kochansky-Devidé \& Pantic: (b) sample 1874, (c) sample 3115E. (d, e) Planiinvoluta? mesotriasica Baud, Zaninetti \& Bronnimann, sample 3115E. (f-i) Arenovidalina chialingchiangensis Ho: (f, g, i) sample 1886, (h) sample 3011A. (j, k) Arenovidalina chialingchiangensis rhombea Ho, sample 1886. (1, m) 
fore-reef environment. The foraminiferal fauna include Decapoalina schaeferae, Lenticulina sp. and Opthalmidium sp. (Fig. 9, sample 3113-ST-2) and indicates a Norian-Rhaetian age, although some of the agglutinating forms recognized in the upper part of the block are suggestive of the lowermost Jurassic. A $20 \mathrm{~cm}$ large reddish limestone clast east of Çal village also contains Norian-Rhaetian foraminifera of Aulotortus communis, Aulotortus sp., Auloconus? sp., Semiinvoluta sp., Planiinvoluta carinata, Caronipora sp. and Lenticulina sp. (Fig. 9, sample 1829). These blocks can be compared with the uppermost Triassic limestone block described from the Karakaya Complex in NW Turkey (Okay \& Altıner, 2004).

\section{4.b. Upper Triassic - ?Lower Jurassic turbidites: the Akgöl Formation}

The Akgöl Formation, which includes the MiddleUpper Triassic limestone blocks, consists of black shale intercalated with thin beds of dark siltstone and sandstone (Fig. 11a); the average shale to siltstone and sandstone ratio is $65: 35$, although their distribution is highly uneven with black shale making up over $90 \%$ in some outcrops. The sandstones are generally thinly to medium-bedded, generally fine grained and of greywacke type. Graded bedding is observed in some outcrops; sole marks are rare. The sandstones are poorly sorted, and consist mainly of angular quartz, feldspar and rock clasts; the latter are dominated by andesitic and more acidic volcanic rocks. The sedimentological features indicate a distal turbidite fan. The geochemistry of the shale and sandstone suggests deposition in an active continental margin (Ustaömer \& Robertson, 1994). The thickness of the flysch is difficult to determine because of strong deformation but is in excess of $2000 \mathrm{~m}$. In most outcrops the Akgöl Formation shows intense deformation by shearing and folding, and has been transformed into a broken formation (Fig. 11b). The wavelength of the folding is at the metre to decimetre scale. This intense deformation is not observed in the stratigraphically overlying Upper Jurassic sequences or in the Middle Jurassic intrusive rocks and hence is constrained to latest Triassic or Early Jurassic time. The Akgöl Formation is not metamorphosed; however, the illite crystallinity indicates high diagenetic conditions (Ustaömer \& Robertson, 1994).
The Akgöl Formation is intruded by Middle Jurassic (Bathonian-Callovian) dacite-porphyries and granitoids (Yılmaz \& Boztuğ, 1986; Okay et al. 2014) and is unconformably overlain by the Upper Jurassic (Kimmeridgian) - Lower Cretaceous limestones (Fig. 11c, d), which provide an upper age limit. The lower age limit is set by the Carnian and Norian limestone blocks (Kozur et al. 2000; this study). Clastic zircons from a sandstone sample from the Akgöl Formation are dominated by Permian and Triassic zircons (Karslioğlu et al. 2012).

The only precise palaeontological data on the age of the Akgöl Formation, with photographs and information on location, is the trace fossil Torlessia sp., which indicates a Late Triassic (Carnian-Norian) age (Kozur et al. 2000). During our study we found a siltstone bed in the Akgöl Formation (location 1833 in Fig. 6, UTM coordinates 36T 0578661-4625270) containing thin-shelled bivalves identified as Monotis salinaria (Fig. 11e, identification by Leopold Krystyn), characteristic of the Norian (e.g. McRoberts, 2010). This constitutes the first precise fossil identification from the Akgöl Formation. The same bivalve species also occurs in the Tauric series in Crimea (Fig. 11f). In summary, the palaeontological data indicate a Late Triassic (Norian) age for the Akgöl Formation; its age may go into the Early Jurassic, as generally accepted for the Tauric flysch in Crimea.

\section{4.c. Upper Triassic dismembered ophiolite}

Associated with the turbidites of the Akgöl Formation there are thick sequences of basaltic pillow lavas and pillow breccias (Fig. 12; Bailey, Barnes \& Hupfer, 1967; Ustaömer \& Robertson, 1994). The basalts are tholeiitic and mostly of mid-ocean ridge (MORB) type with some analyses falling in the island-arc tholeiite field (Ustaömer \& Robertson, 1994). Most of the contacts between the basalt and turbidite are represented by faults; however, at a few localities basaltic pillow lavas and pillow breccias are overlain stratigraphically by black shales of the Akgöl Formation (Fig. 11g), as also observed by Bailey, Barnes \& Hupfer (1967) and Ustaömer \& Robertson (1994). The ancient Küre copper mine with chalcopyrite and pyrite as the main ore minerals is located along the contact between the basalt and black shale (Fig. 11h); the mineralization has developed mainly in the basalt (Bailey, Barnes \& Hupfer,

Arenovidalina amylovoluta Ho, sample 1867; (n-p) Arenovidalina spp.: (n, o) sample 1886, (p) sample 3011A. (q) Arenovidalina sp. or Eoophthalmidium sp., sample 1886. (r) Ophthalmidium? ubeyliense Dağer, sample 3011A. (s, t) Eoophthalmidium tricki Langer: (s) sample 3011A, (t) sample 1886. (u) Decapoalina schaeferae (Zaninetti, Altıner, Dağer \& Ducret), sample 3113-ST-2. (v) Ophthalmidium sp., sample 1886. (w) Hoyenella sp., sample 1886. (x) Turriglomina mesotriasica (Koehn-Zaninetti), sample 1890. (y) Turriglomina mesotriasica (Koehn-Zaninetti) form B?, sample 1889. (z) Turriglomina scandonei Zaninetti, Ciarapica, Martini, Salvini-Bonnard \& Rettori, sample 1889. (aa, bb) Trochammina almtalensis Koehn-Zaninetti: (aa) sample 1869, (bb) sample 3115E. (cc) Gsolbergella spiriloculiformis (Oraveczne Scheffer), sample 1890. (dd) Cucurbita sp., sample 1890. (ee) Endoteba controversa Vachard \& Razgallah, sample 3115E. (ff, gg) Endoteba kuepperi (Oberhauser), sample 1890. (hh) 'Nodosaria' elabugae Cherdyntsev, sample 1874. (ii) 'Nodosaria' skyphica Efimova, sample 1886. (jj) Tubiphytes obscurus Maslov, sample 1890. (kk) Baccanella floriformis Pantic, sample 1890. (11) Auloconus ? sp., sample 1829B. (mm) Aulotortus communis (Kristan), sample 1829B. (nn) Planiinvoluta carinata Leischner, sample 1829A. (oo) Semiinvoluta sp., sample 1829B. Scale bars equal $100 \mu \mathrm{m}$. 


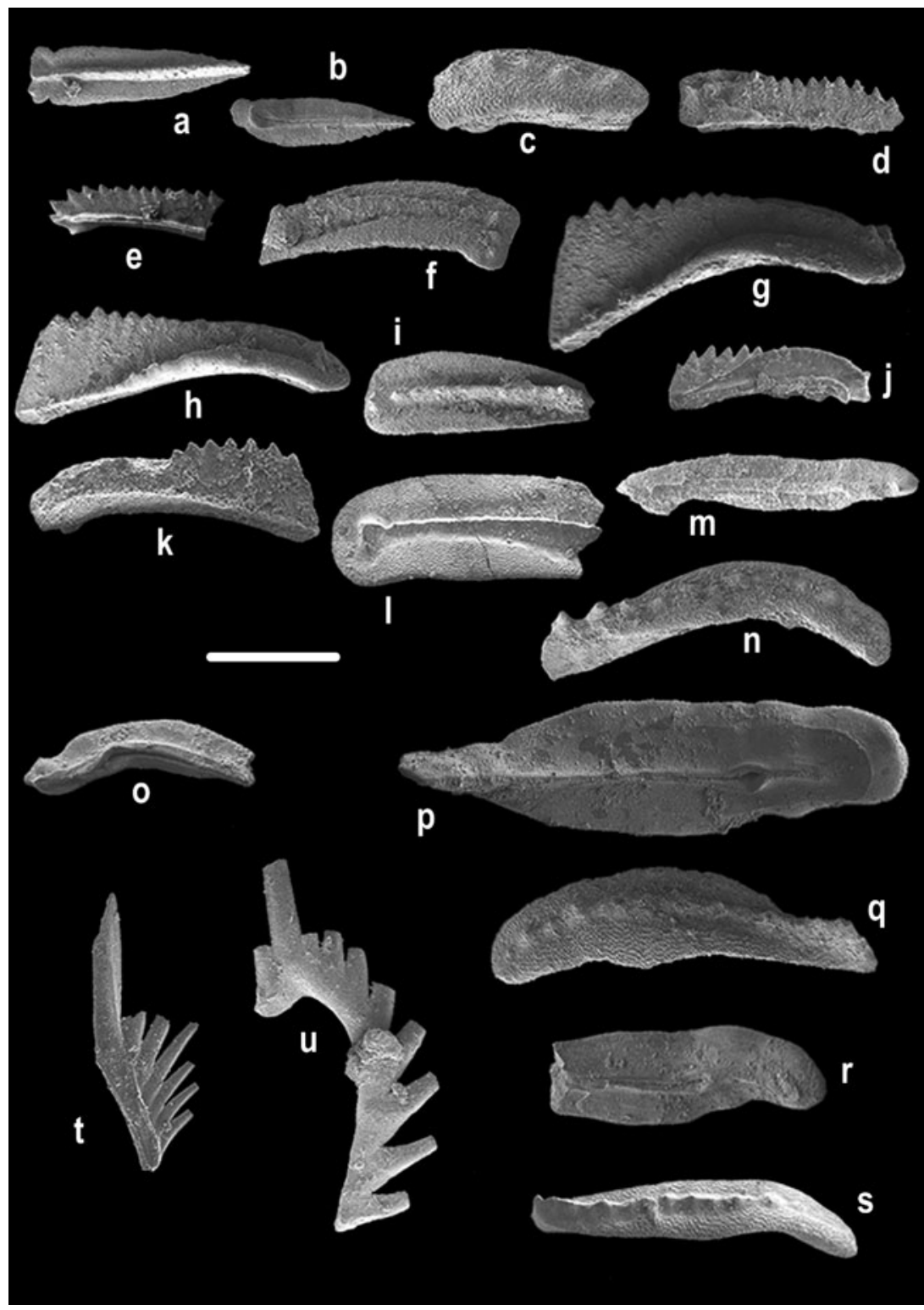

Figure 10. Electron microscope images of conodonts from the Kayabaşı Formation. For location of the specimens see Figure 6. (a, b) Neogondolella constricta, Mosher \& Clark; middle-upper Illyrian - lower Fassanian (upper Anisian - lower Ladinian): (a) upper view; adult specimen shows constriction near posterior end and probable slight bifid basal cavity, sample 1897; (b) lower view; younger specimen, small loop-like pit, sample 1897. (c) Gladigondolella malayensis, Nogami; Julian (Carnian); sample 1895. (d) Metapolygnathus tadpole (Hayashi); Cordevolian - lower Tuvalian (Carnian); angular view, sample 1895. (e) Neogondolella regalis (Mosher); middle Aegean - Bithynian (Anisian); sample 1868. (f) Metapolygnathus inclinatus (Kovarcs); Julian (Carnian); sample 1895. (g-i) Metapolygnathus cf. fuelopi; Ladinian; sample 1889. (j) M. Gr. inclinatus; Julian (Carnian); sample 1894. (k, 1) Metapolygnathus Gr. excelsus-inclinatus; Late Ladinian - Early Carnian; sample 1889. (m-u) Gladigondolella tethydis; Middle Triassic: (m-s) P element, (t) S1, (u) M element; (m, n) sample 1892, (o-u) sample 1889. Scale bar equals $500 \mu \mathrm{m}$

1967). Apart from the basalt, there are a few hundredmetre-sized bodies of gabbro and plagioclase-lherzolite within the basalts. The plagioclase-lherzolites consist mainly of olivine, plagioclase and clinopyroxene (Çakır, Genç \& Paktunç, 2006) and are probably cumulate bodies.

Serpentinite occurs as large slices in the turbidites of the Akgöl Formation. Because of its significance as a possible mantle rock, the serpentinite was mapped in detail (Fig. 12). It occurs as up to $4 \mathrm{~km}$ long tectonic slices surrounded by shale and sandstone of the Akgöl Formation, and consists of completely serpentinized massive harzburgite. The lack of serpentinite clasts or debris flows in the surrounding sandstone-shale sequence indicates that the serpentinite was emplaced tectonically.

The age of the serpentinite is critical for the tectonic interpretation of the Akgöl Formation. Cretaceous ophiolitic melange with serpentinite slivers occurs $40 \mathrm{~km}$ south of the serpentinite outcrop (Fig. 3), and the serpentinite could have been emplaced any time after the Late Triassic and possibly during Cretaceous time. The serpentinite and the turbidites of the Akgöl Formation are intruded by the Karaman granitoid, which forms an intrusive body measuring $5 \mathrm{~km}$ by $5 \mathrm{~km}$ (Fig. 12). It is part of a series of 

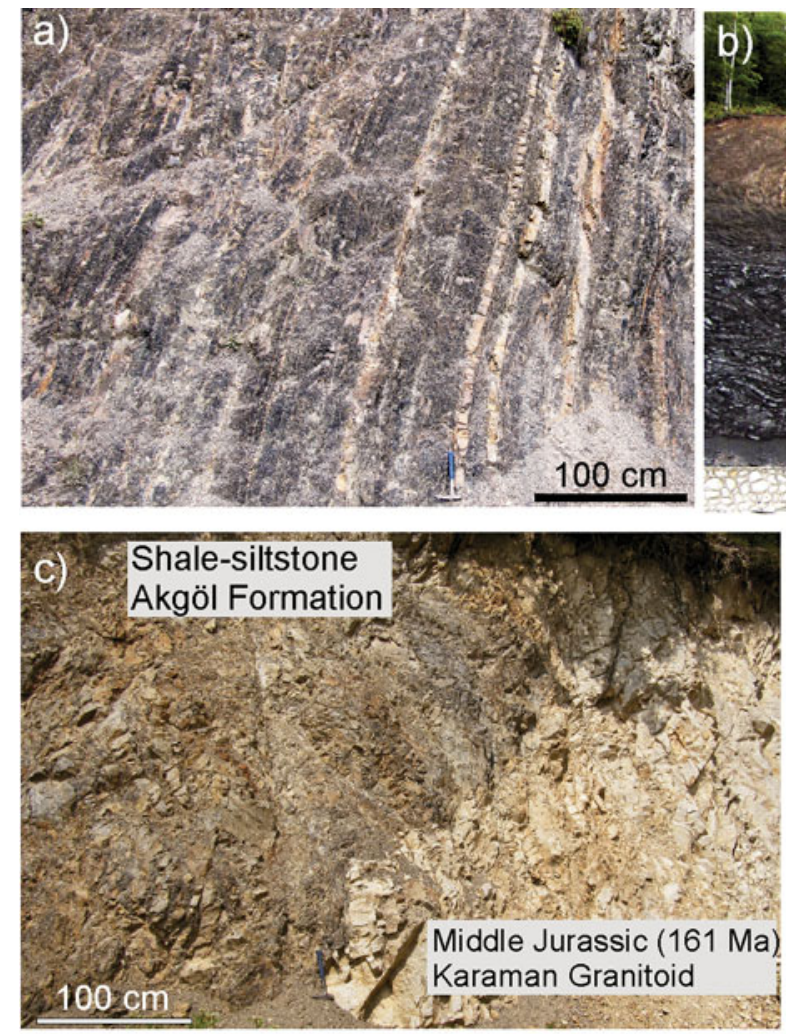

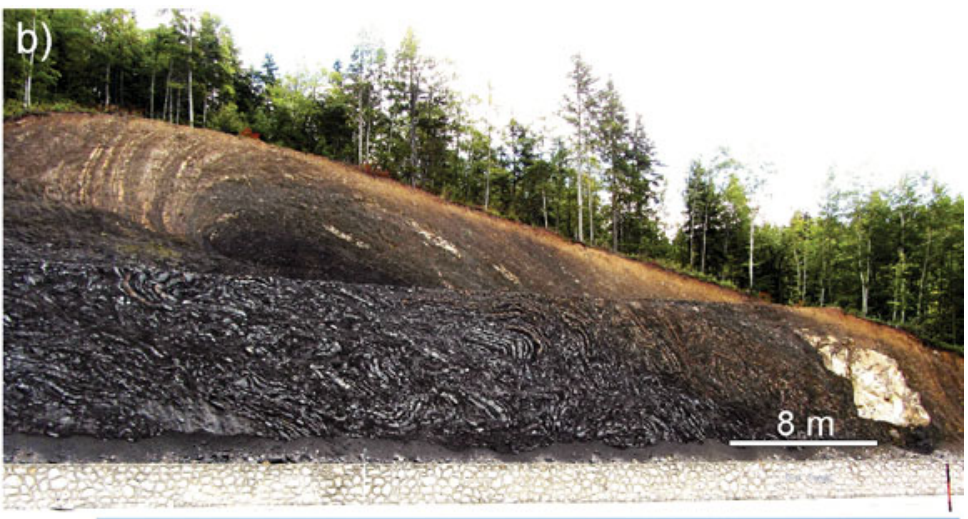

d)
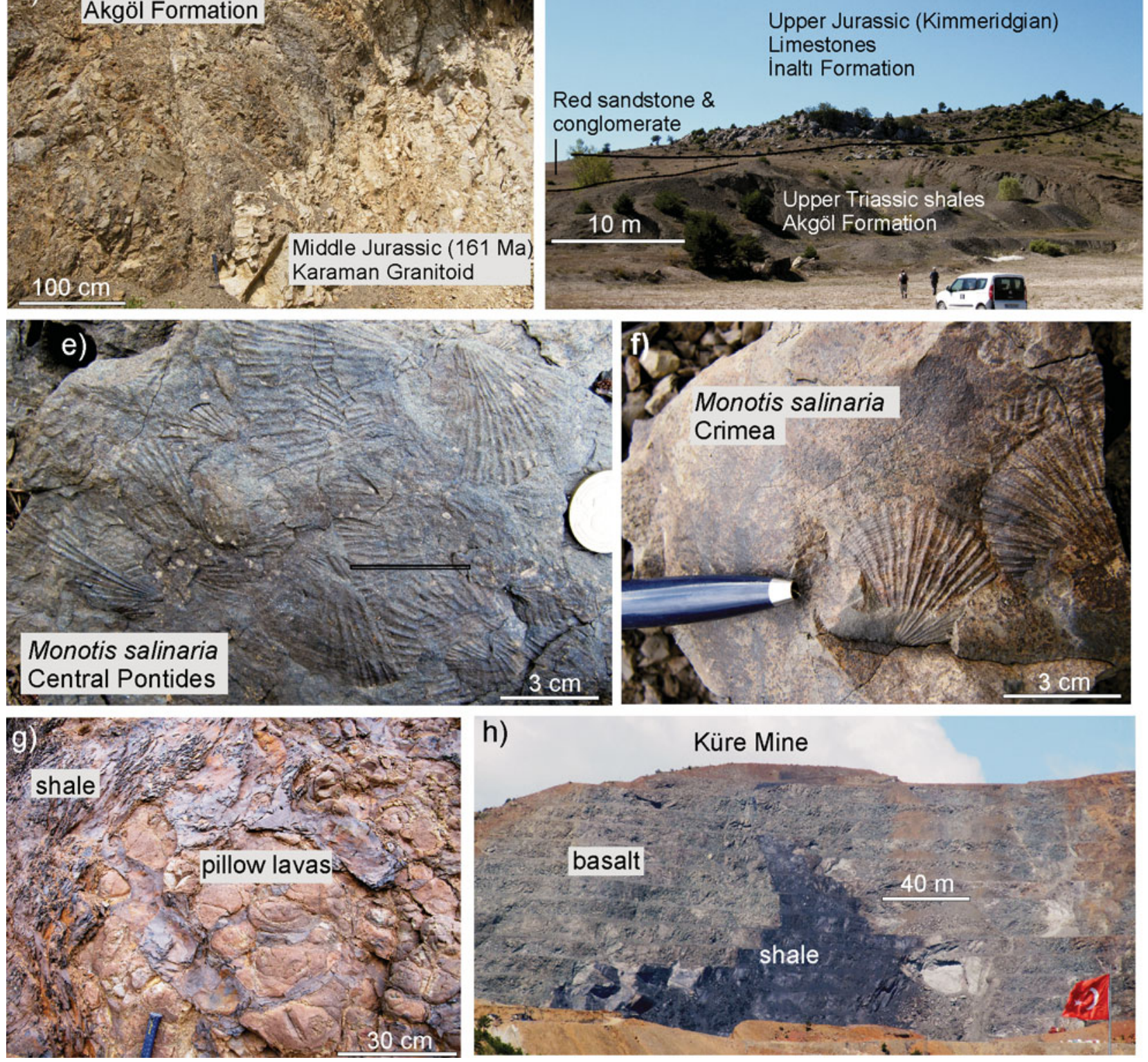

h)

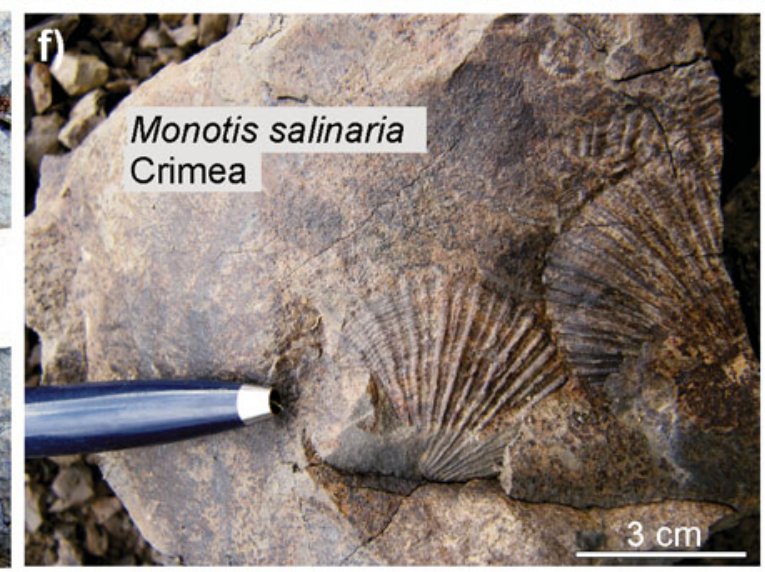

Küre Mine

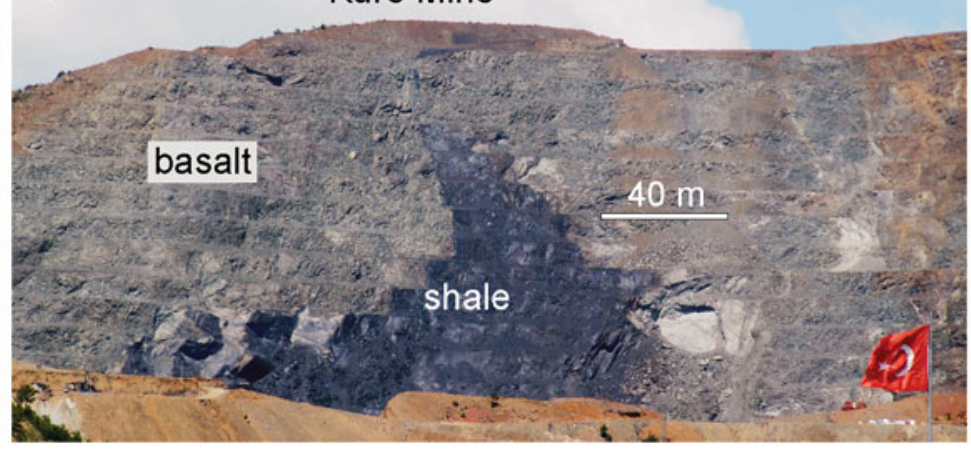

Figure 11. (Colour online) Field photographs from the Triassic Küre Complex. (a) Distal turbidites of the Upper Triassic Akgöl Formation. (b) Sheared and folded turbidites of the Akgöl Formation; the light coloured block on the right is a sandstone boudin. (c) The Akgöl Formation intruded by the Middle Jurassic Karaman Granitoid. (d) Black shales of the Akgöl Formation overlain unconformably by the fluviatile red sandstone and conglomerate and by the shallow marine limestones of the Upper Jurassic (Kimmeridgian) İnalt1 Formation. (e, f) The Late Triassic (Norian) bivalve Monotis salinaria in the siltstones of the Akgöl Formation in the Central Pontides (sample 1833) (e) and in the Tauric flysch in Crimea (location 54, Table S2 in the online Supplementary Material available at http://journals.cambridge.org/geo) (f). (g) Basaltic pillow lavas overlain stratigraphically by the black shales of the Akgöl Formation. (h) Black shale and basalt in the Küre mine; the chalcopyrite mineralization occurs in the shales along the contact. The height of the mine face is approximately $70 \mathrm{~m}$. 


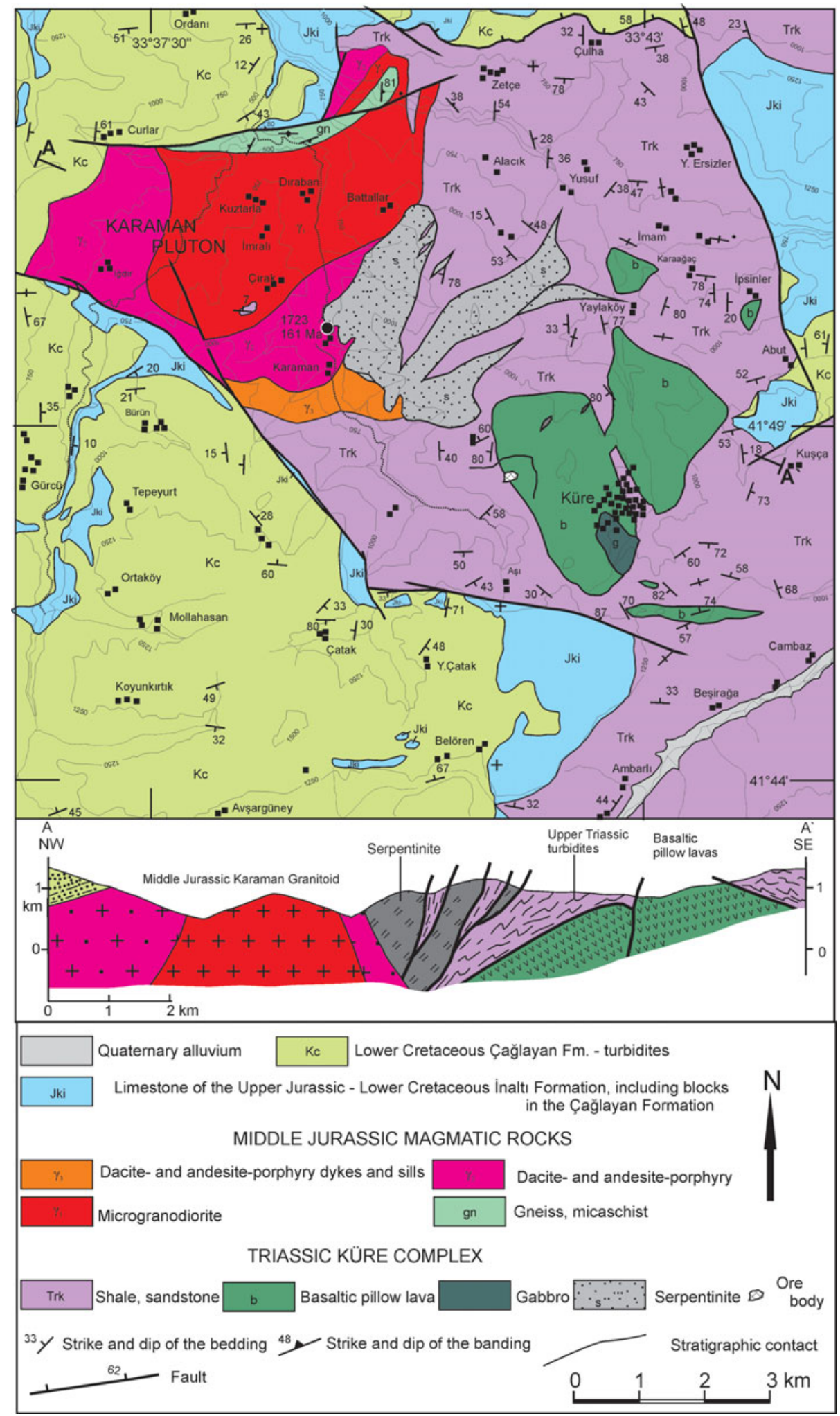

Figure 12. (Colour online) Geological map and cross-section of the Küre region based on Bailey, Barnes \& Hupfer (1967), O. Tüysüz et al. (unpub. report, 2000), Okay et al. (2014) and this study. For location see Figure 3.

Middle Jurassic intrusions emplaced along a major magmatic arc (Yılmaz \& Boztuğ, 1986; Okay et al. 2014). The Karaman intrusion has a zonal structure with a core of medium-grained microgranodiorite to microdiorite surrounded by dacite-porphyry. The microgranodiorite, which makes up the bulk of the intrusion, has the mineral assemblage of plagioclase + biotite + quartz \pm hornblende \pm cordierite (Okay et al. 2014). The marginal dacite-porphyry consists of plagioclase, biotite and quartz and locally hornblende phenocrysts in a fine-grained matrix of the same minerals. To constrain the age of the 
serpentinite, we dated ten biotite grains from a dacite-porphyry sample (1723), which gave a coherent age of $162 \pm 4 \mathrm{Ma}$ (Table 2; Okay et al. 2014). This shows that the serpentinite was emplaced prior to Middle Jurassic time. Considering the association of serpentinite with the Upper Triassic turbidites and pillow lavas, a Triassic age is likely for the serpentinite. The serpentinite, gabbro and basalt most probably constitute a dismembered ophiolite on which the Upper Triassic to ?Lower Jurassic turbidites of the Akgöl Formation were deposited (Ustaömer \& Robertson, 1994).

\section{Comparison with the Tauric Flysch in Crimea}

Upper Triassic turbidites in the Central Pontides and those in Crimea share several common features. (1) In both regions the Upper Triassic sequence consists predominantly of distal siliciclastic turbidites, with a dominance of black shales. (2) At least part of the turbidite sequence is of Late Triassic (Norian) age based on the macrofauna. Monotis salinaria, a bivalve characteristic for the Norian, is found both in the Crimea and Central Pontides (Fig. 11e, f). The turbidite sequence in Crimea is thought to extend into the Lower Jurassic. (3) Clastic zircon populations from both regions are similar (Karshıoglu et al. 2012; A. Nikishin pers. comm.) with a dominance of Triassic and PermoCarboniferous zircons. (4) The turbidites in the Crimea and Central Pontides have undergone a strong contractional deformation during latest Triassic - Early Jurassic time. (5) They are intruded or overlain by Middle Jurassic magmatic rocks. Upper Jurassic shallow marine carbonates lie also unconformably over the Triassic flysch. These features indicate that prior to the Late Cretaceous opening of the Black Sea as a back-arc basin (e.g. Okay, Şengör \& Görür, 1994), the Upper Triassic turbidites in Crimea and in the Central Pontides were contiguous and were deposited in the same basin.

\section{Discussion}

\section{6.a. Late Triassic fore-arc basin on the southern active margin of Laurasia}

The pre-Permian basement in the Central Pontides consists of a low-grade metasedimentary sequence of interbedded sandstone and shale. The flyschoid character of the sequence and the presence of pre-Permian serpentinite slivers suggest deposition on a Palaeozoic active margin. The Palaeozoic metasedimentary rocks are intruded by the Late Carboniferous and Early Permian granitoids. A Variscan granitoidic basement in the Central Pontides is also reflected in the high percentage of Permian and Carboniferous zircons in the Triassic (Karslığlu et al. 2012) and Lower Cretaceous turbidites (Okay et al. 2013). This crystalline basement was probably overlain by Triassic carbonates, represented by the Kayabaş1 Formation in the Central Pontides.
However, absence of Triassic carbonates along the contacts between the late Variscan basement and the Upper Triassic turbidites (Fig. 3) suggests a period of uplift and deformation during Carnian time. The buried Late Triassic volcanic arc in the Scythian Platform in the north (Fig. 1; Tikhomirov, Chalot-Prat \& Nazarevich, 2004) and Upper Triassic eclogites and blueschists in the southwest (Okay \& Monié, 1997; Okay, Monod \& Monié, 2002) suggest that the Upper Triassic turbidites were deposited in a fore-arc basin on the southern margin of Laurasia (Fig. 13a, b). In the north the forearc basin rested on continental crust and in the south on oceanic crust, similar to the Great Valley Group in California (e.g. Ingersoll, 1979).

Disrupted Upper Triassic clastic sequences are widespread in the Sakarya Zone in NW Turkey, where they are known as the Upper Karakaya Complex (Fig. 1; Okay \& Göncüoğlu, 2004). They contain olistoliths of Middle Triassic, as well as Permian and Carboniferous limestones in an Upper Triassic clastic matrix (Kaya, 1991; Wiedmann, Kozur, \& Kaya, 1992; Leven \& Okay, 1996; Altıner, Özkan-Altıner \& Koçyı̆̆ıt, 2000). Within the Upper Triassic clastic sequences there are also rare blocks of Permian, Carboniferous and Devonian radiolarian cherts (Okay \& Mostler, 1994; Kozur \& Kaya, 1994; Göncüoğlu et al. 2004; Okay, Noble \& Tekin, 2011). The Upper Karakaya Complex shares several common features with the Akgöl Formation of the Central Pontides, including tectonic setting, lithology and age, and was most probably deposited in same fore-arc on the southern margin of Laurasia. The Tauric flysch in Crimea and the Dizi Series in the Caucasus likely formed part of the same basinal deposits.

The Küre basin is commonly described as a back-arc basin (e.g. Ustaömer \& Robertson, 1993, 1994; Barrier \& Vrielynck, 2008; Nikishin et al. 2012); this was based on the presence of 'Permo-Triassic' subductionaccretion complexes (Domuzdağ 1 and Elekdağ complexes) and a Permo-Triassic magmatic arc (Çangaldağ Complex) south of the Küre Complex (Fig. 3). However, recent work has shown that the Domuzdağı and Elekdağ complexes are Early Cretaceous and the Çangaldağ Complex Middle Jurassic in age (Okay et al. 2006, 2013, 2014), and there is no Triassic or older unit between the Küre Complex and the İzmir-Ankara suture. Thus, during Triassic time the Küre basin was directly facing the Tethyan ocean in the south (Fig. 13).

\section{6.b. Latest Triassic deformation and the Cimmeride orogeny}

A transition from carbonate to clastic deposition is observed in Late Triassic time throughout the circumBlack Sea region, including in the western part of the Istanbul Zone (Yurttaş-Özdemir, 1971; Gedik, 1975), in Dobrugea (Seghedi, 2001) and in the Balkans (Tari et al. 1997). In latest Triassic and/or earliest Jurassic time, this clastic basin was inverted, and the circumBlack Sea region, including the Greater Caucasus and the Scythian Platform, was uplifted and eroded (e.g. 

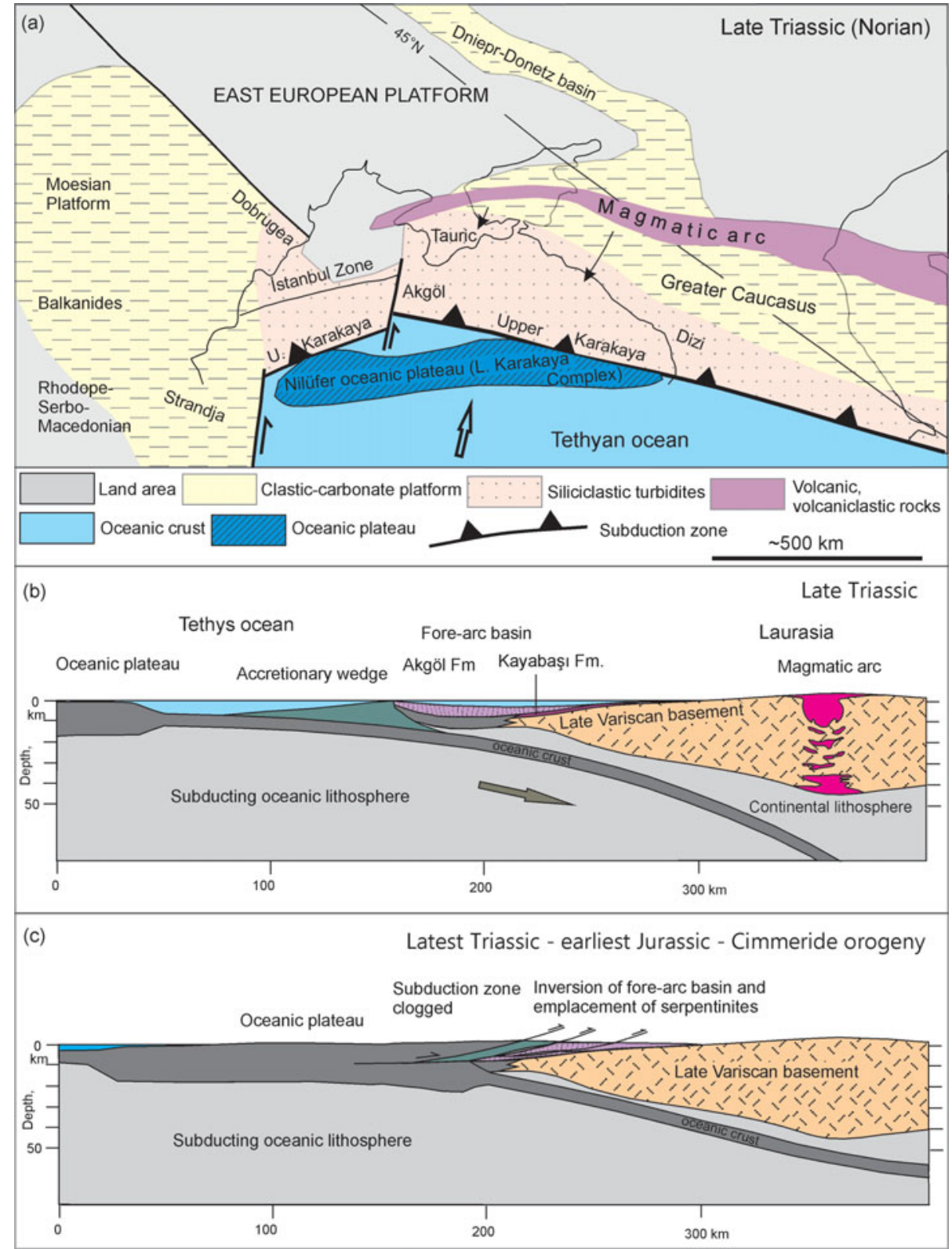

Figure 13. (Colour online) Palaeogeographic map and cross-sections for the Late Triassic to Early Jurassic showing the palaeogeographic location and evolution of the tectonic units discussed in the text (based on Hamilton, 1988; Barrier \& Vrielynck, 2008; Nikishin et al. 2012).

Gaetani et al. 2005; Nikishin et al. 2012). In the Central Pontides this was associated with the emplacement of serpentinites, and in NW Turkey that of the uppermost Triassic eclogites and blueschists. The Cimmeride deformation was short lived; the unconformable sedimentary cover over the Cimmeride units is Early Jurassic (Sinemurian) in age in NW Turkey (Altıner et al. 1991). In the Central Pontides, the deformed Upper Triassic turbidites and the serpentinite are cut by undeformed Middle Jurassic (Bathonian-Callovian) acidic intrusions.

The Late Triassic deformation in the circum-Black Sea region was ascribed to the collision of a Cimmeride continent or continental blocks (e.g. Şengör, 1984). However, Triassic, Jurassic and Cretaceous accretionary complexes in the Pontides are directly juxta- posed without any intervening continental crustal material (Okay, 2000; Çelik et al. 2011; Topuz et al. 2013, in press). Furthermore, the brief period of deformation, constrained to $c$. $10 \mathrm{Ma}$ in the latest Triassic - earliest Jurassic (Rhaetian-Hettangian), makes a continentcontinent collision an unlikely cause for the Cimmeride orogeny.

During Late Triassic time, large thicknesses of mafic crustal material were accreted to the southern margin of Laurasia. These are known in the Sakarya Zone as the Lower Karakaya Complex or the Nilüfer Unit (Okay, 2000; Okay \& Göncüoğlu, 2004; Pickett \& Robertson, 2004; Robertson \& Ustaömer, 2012). The Lower Karakaya Complex shows metamorphism mainly to greenschist facies but also includes uppermost Triassic eclogites and blueschists (Okay \& Monié, 
1997; Okay, Monod \& Monié, 2002). The geochemistry of the metabasites in the Lower Karakaya Complex shows within-plate characteristics; this is interpreted as formation in oceanic islands or in an oceanic plateau in Permo-Triassic time (Okay, 2000; Genç, 2004; Pickett \& Roberson, 2004; Sayit \& Göncüoğlu, 2013; Catlos, Hubert \& Shin, 2013). We suggest that the incipient collision of this oceanic edifice in Late Triassic time caused uplift along the Laurasian margin resulting in clastic sedimentation in the fore-arc region (Fig. 13c). This was followed by collision and accretion, which resulted in the inversion and deformation of the forearc basin.

\section{Conclusions}

(1) In the northern Central Pontides there is a pre-Permian basement of low-grade metasedimentary rocks with pre-Permian serpentinite lenses and intrusive Late Permian and Early Carboniferous granitoids (Figs 3, 4). The basement is overlain by the Upper Triassic turbidites. Similar basement rocks should be present under Crimea and under the Scythian Platform.

(2) In the Central Pontides a $550 \mathrm{~m}$ thick sequence of hemi-pelagic to pelagic Hallstatt-type limestone occurs as a large olistolith in the Upper Triassic turbidites. Conodonts and foraminifera indicate that the limestone sequence is Anisian to Carnian in age. The surrounding turbidites contain the bivalve Monotis salinaria, which indicates a Late Triassic (Norian) age for the clastic sequence. The same fossil is also described from the Tauric flysch in Crimea.

(3) The Upper Triassic turbidites are locally underlain by basaltic pillow lavas and contain kilometresized tectonic slices of serpentinite. The turbidites and the serpentinite are intruded by Middle Jurassic age (162 Ma) granitoids (Fig. 12), showing that the serpentinite is pre-Middle Jurassic in age. The Upper Triassic turbidites are deposited in a fore-arc basin above a northward-dipping subduction zone (Fig. 13). The Triassic magmatic arc is located subsurface in the Scythian Platform north of the Black Sea (Fig. 1).

(4) The Upper Triassic turbidites are strongly deformed by folding, faulting and shearing. This deformation is not observed in the Middle Jurassic magmatic rocks or in the overlying Upper Jurassic conglomerates and limestones, indicating that the deformation is of latest Triassic and/or Early Jurassic age.

(5) Data from the Central Pontides and regional geological constraints indicate that the latest Triassic to Early Jurassic Cimmeride deformation is related to accretion of large oceanic edifices to the southern margin of Laurasia rather than to a collision with a Cimmerian continent.

Acknowledgements. This study was supported by TÜBITAK grant 109Y049 and partly by TÜBA. We thank Sarah Sherlock for the Ar-Ar analyses, Leopold Krystyn for discussion and palaeontological determination, Gürsel Sunal for assisting in mineral separation and Anatoly Nikishin for lead- ing the field trip in Crimea. Andrea Zanchi and an anonymous reviewer are thanked for their pertinent and constructive comments.

\section{Supplementary material}

To view supplementary material for this article, please visit http://dx.doi.org/10.1017/S0016756814000429.

\section{References}

Adamia, S., Zakariadze, G., ChKhotua, T., SAdradze, N., TSEREteli, N., ChabuKiani, A. \& GventsadZe, A. 2011. Geology of the Caucasus: a review. Turkish Journal of Earth Sciences 20, 489-544.

AKsay, A., Pehlivan, Ş., GediK, İ., Bilginer, E., Duru, M., AKBAȘ, B. \& Altun, İ. 2002. Geological Map Series of Turkey, Zonguldak Sheet, 1: 500 000. Ankara: Maden Tetkik ve Arama Genel Müdürlüğü.

Alexandre, P., Chalot-Prat, F., SAintot, A., WijBrans, J., Stephenson, R., Wilson, M., KitchKa, A. \& StOVBA, S. 2004. The ${ }^{40} \mathrm{Ar} /{ }^{39} \mathrm{Ar}$ dating of magmatic activity in the Donbas Fold Belt and the Scythian Platform (Eastern European Craton). Tectonics 23, TC5002.

Altiner, D., KoçyiĞIT, A., FARINACCI, A., Nicosia, U. \& CoNTI, M. A. 1991. Jurassic-Lower Cretaceous stratigraphy and paleogeographic evolution of the southern part of north-western Anatolia. Geologica Romana 28, 13-80.

Altiner, D., ÖZKan-Altiner, S. \& KoçYiğIT, A. 2000. Late Permian foraminiferal biofacies belts in Turkey: palaeogeographic and tectonic implications. In Tectonics and Magmatism in Turkey and Surrounding Area (eds E. Bozkurt, J. A. Winchester \& J. A. D. Piper), pp. 8396. Geological Society of London, Special Publication no. 173 .

ASSERETO, R. 1972. Notes on the Anisian biostratigraphy of the Gebze area (Kocaeli Peninsula, Turkei). Zeitschrift der Deutschen Geologischen Gesellschaft 123, 435-44.

AYDIN, M., DEMIR, O., ÖZÇELIK, Y., TERZIOĞLU, N. \& SATIR, M. 1995. A geological revision of İnebolu, Devrekani, Ağlı and Küre areas: new observations in PaleoTethys NeoTethys sedimentary successions. In Geology of the Black Sea region (eds A. Erler, T. Ercan, E. Bingöl \& S. Örçen), pp. 33-8. Ankara: MTA/JMO Publication.

Bailey, E. H., BARnes, J. W. \& HuPfER, D. H. 1967. Geology and ore deposits of the Küre district, Kastamonu province, Turkey. In Geological Mapping Techniques, CENTO Summer Training Programme, pp. 17-74. Ankara: MTA Publications.

BARRIER, E. \& VRIELYNCK, B. 2008. MEBE Atlas of the Paleotectonic Maps of the Middle East. Paris: Commission for the Geological Map of the World.

Bedi, Y., VAsilev, E., DABOVSKi, C., ERgen, A., OKuYucu, C. Z., DoĞAN, A., TeKIN, U. K., IVANOVA, D., Boncheva, I., Lakova, I., Sachanski, V., Kuşçu, İ., Tuncay, E., Demiray, D. G., Soycan, H. \& GÖNCÜOĞLU, C. 2013. New age data from the tectonostratigraphic units of the Istranca "Massif" in NW Turkey: a correlation with SE Bulgaria. Geologica Carpathica 64, 255-77.

Blumenthal, M. M. 1948. Geology of the North Anatolian Mountain Ranges Between Bolu and Lower Kuzllırmak (in Turkish). Ankara: Maden Tetkik ve Arama Enstitüsü Publication, Series B, no. 13, 265 pp.

BoztuĞ, D., Debon, F., Le Fort, P. \& Yilmaz, O. 1984. Geochemical characteristics of some plutons from the Kastamonu granitoid belt (Northern Anatolia, Turkey). 
Schweizerische Minerologische und Petrographische Mitteilungen 64, 389-404.

BoztuĞ, D., Debon, F., Le Fort, P., Yilmaz, O. 1995. High compositional diversity of the Middle Jurassic Kastamonu Plutonic Belt, northern Anatolia, Turkey. Turkish Journal of Earth Sciences 4, 67-86.

BozTUĞ, D. \& YILMAZ, O. 1983. Mineralogical-petrographic and geochemical study of the Büyükçay-Elmalıçay granitoid (Kastamonu) and its country rocks (in Turkish). Yerbilimleri 10, 71-88.

ÇAKIR, Ü., GENÇ, Y. \& PAKTUNÇ, D. 2006. Intrusive lherzolites within the basalts of Küre ophiolite (Turkey): an occurrence in the Tethyan suprasubduction marginal basin. Geological Journal 41, 123-43.

Catlos, E., Hubert, K. \& Shin, T. A. 2013. Geochemistry and geochronology of meta-igneous rocks from the Tokat Massif, north-central Turkey: implications for Tethyan reconstructions. International Journal of Earth Sciences 102, 2175-98.

ÇElik, Ö. F., Marzoli, A., Marschik, R., Chiaradia, M., NeUBAUER, F. \& Öz, İ. 2011. Early-Middle Jurassic intra-oceanic subduction in the İzmir-Ankara-Erzincan Ocean, Northern Turkey. Tectonophysics 539, 120 34.

Chen, F., Siebel, W., Satir, M., Terzioğlu, N. \& SaK, K. 2002. Geochronology of the Karadere basement (NW Turkey) and implications for the geological evolution of the Istanbul Zone. International Journal of Earth Sciences 91, 469-81.

ClIFF, R. A. 1985. Isotopic dating in metamorphic belts. Journal of the Geological Society, London 142, 97-110.

Cohen, K. M., Finney, S. C., GibBard, P. L. \& FAn, J.-X. 2013. The ICS International Chronostratigraphic Chart. Episodes 36, 199-204.

Dean, W. T., Monod, O., Rickards, R. B., Demir, O. \& BULTYNCK, P. 2000. Lower Palaeozoic stratigraphy and palaeontology, Karadere-Zirze area, Pontus Mountains, northern Turkey. Geological Magazine 137, 555-82.

Derman, A. S. 2002. Black Sea rift sequences. Türkiye Petrol Jeologlarl Derneği Bülteni 14, 36-65.

Gaetani, M., Garzanti, E., Polino, R., Kiricko, Y., Korsakhov, S., Cirilli, S., Nicora, A., RetTori, R., LARGHI, C. \& PALliani, R. B. 2005. Stratigraphic evidence for Cimmerian events in NW Caucasus (Russia). Bulletin de la Société Géologique de France 176, 283 99.

GEDIK, I. 1975. Die Conodonten der Trias auf der KocaeliHalbinsel (Türkei). Palaeontographica 150, 99160.

GENÇ, S. C. 2004. A Triassic large igneous province in the Pontides, northern Turkey: geochemical data for its tectonic setting. Asian Journal of Earth Sciences 22, 50316.

GöncÜOĞLU, M. C., Kuwahara, K., Tekin, K. U. \& TuRHAN, N. 2004. Upper Permian (Changxingian) radiolarian cherts within the clastic successions of the Karakaya Complex in NW Anatolia. Turkish Journal of Earth Sciences 13, 201-13.

GÖrÜr, N., MONOD, O., OKAY, A. I., ŞENGÖR, A. M. C., TÜYsÜZ, O., YIĞITBAŞ, E., SAKINÇ, M. \& AKKÖK, R. 1997. Palaeogeographic and tectonic position of the Carboniferous rocks of the western Pontides (Turkey) in the frame of the Variscan belt. Bulletin de la Société Géologique de France 168, 197-205.

HAMILTON, W. B. 1988. Plate tectonics and island arcs. Geological Society of America Bulletin 100, 1503-27.

HANEL, M., GuRBANOV, A. G. \& LiPPOLT, H. J. 1992. Age and genesis of granitoids from the Main-Range and Becha- syn zones of the western Great Caucasus. Neues Jahrbuch für Mineralogie Monatshefte 12, 529-44.

INGERSOLL, R. V. 1979. Evolution of the Late Cretaceous forearc basin, northern and central California. Geological Society of America Bulletin 90, 813-26.

KARSLIOĞLU, Ö., Ustä̈mer, T., Robertson, A. H. F. \& PEYTCHEVA, I. 2012. Age and provenance of detrital zircons from a sandstone turbidite of the Triassic-Early Jurassic Küre Complex, Central Pontides. Abstracts, International Earth Science Colloquium on the Aegean Region, IAESCA-2012, p. 57.

KAYA, O. 1991. Stratigraphy of the pre-Jurassic sedimentary rocks of the western parts of Turkey: type area study and tectonic considerations. Newsletter for Stratigraphy 23, 123-40.

KozUr, H., AYDIN, M., DEMIR, O., YAKAR, H., GÖNCÜOĞLU, M. C. \& KURU, F. 2000. New stratigraphic and palaeogeographic results from the Palaeozoic and early Mesozoic of the Middle Pontides (northern Turkey) in the Azdavay, Devrekani, Küre and İnebolu areas. Implications for the Carboniferous-Early Cretaceous geodynamic evolution and some related remarks to the Karakaya oceanic rift basin. Geologica Croatica 53, 209-68.

KozUR, H. \& KAYA, O. 1994. First evidence of pelagic Late Permian conodonts from NW Turkey. Neues Jahrbuch für Geologie und Palaontologie, Monatshefte 1994 (6), 339-47.

LEVEN, E. J. \& OKAY, A. I. 1996. Foraminifera from the exotic Permo-Carboniferous limestone blocks in the Karakaya Complex, northwest Turkey. Rivista Italiana Paleontologia e Stratigrafia 102, 139-74.

MCROBERTS, C. A. 2010. Biochronology of Triassic bivalves. In The Triassic Timescale (ed. S. G. Lucas), pp. 201-19. Geological Society of London, Special Publication no. 334.

Muttoni, G., Gaetani, M., Budurov, K., Zagorchev, I., Trifonova, E., Ivanova, D., Petrounova, L. \& LOWRIE, W. 2000. Middle Triassic paleomagnetic data from northern Bulgaria: constraints on Tethyan magnetostratigraphy and paleogeography. Palaeogeography, Palaeoclimatology, Palaeoecology 160, 223-37.

NATAL'IN, B. A. \& ŞENGÖR, A. M. C. 2005. Late Palaeozoic to Triassic evolution of the Turan and Scythian platforms: the pre-history of the Palaeo-Tethyan closure. Tectonophysics 404, 175-202.

Nikishin, A., Ziegler, P., Bolotov, S. \& FoKin, P. 2012. Late Palaeozoic to Cenozoic Evolution of the Black Sea-Southern Eastern Europe Region: a view from the Russian Platform. Turkish Journal of Earth Sciences 21, 571-634.

Nikishin, A. M., Ziegler, P. A., PANOV, D. I., NAZAREVICH, B. P., Brunet, M. F., Stephenson, R. A., Bolotov, S. N., KorotaeV, M. V. \& TikHomirov, P. L. 2001. Mesozoic and Cenozoic evolution of the Scythian PlatformBlack Sea-Caucasus domain. In Peri-Tethys Memoir 6: Peri-Tethyan Rift/Wrench Basins and Passive Margins (eds P. A. Ziegler, W. Cavazza, A. H. F. Robertson \& S. Crasquin-Soleau), pp. 295-346. Memoires du Museum National d'Histoire Naturelle de Paris 186.

NZEGGe, O. M., SATiR, M., SieBel, W. \& TAubald, H. 2006. Geochemical and isotopic constraints on the genesis of the Late Palaeozoic Deliktaş and Sivrikaya granites from the Kastamonu granitoid belt (Central Pontides, Turkey). Neues Jahrbuch für Mineralogie, Abhandlungen 183, $27-40$.

OKAY, A. I. 2000. Was the Late Triassic orogeny in Turkey caused by the collision of an oceanic plateau? In 
Tectonics and Magmatism in Turkey and Surrounding Area (eds E. Bozkurt, J. A. Winchester \& J. A. D. Piper), pp. 25-41. Geological Society of London, Special Publication no. 173.

OKAY, A. I. \& Altiner, D. 2004. Uppermost Triassic limestone in the Karakaya Complex - stratigraphic and tectonic significance. Turkish Journal of Earth Sciences 13, 187-99.

OKAY, A. I. \& GÖNCÜOĞLU, M. C. 2004. Karakaya Complex: a review of data and concepts. Turkish Journal of Earth Sciences 13, 77-95.

OKAY, A. I. \& MONIÉ, P. 1997. Early Mesozoic subduction in the Eastern Mediterranean: evidence from Triassic eclogite in northwest Turkey. Geology 25, 595-8.

OKaY, A. I., MONOD, O. \& MoniÉ, P. 2002. Triassic blueschists and eclogites from northwest Turkey: vestiges of the Paleo-Tethyan subduction. Lithos 64, 155-78.

OKay, A. I. \& Mostler, H. 1994. Carboniferous and Permian radiolarite blocks in the Karakaya Complex in northwest Turkey. Turkish Journal of Earth Sciences 3, $23-8$.

OKay, A. I., Noble, \& P. J. TeKin, U. K. 2011. Devonian radiolarian ribbon cherts from the Karakaya Complex, northwest Turkey: implications for the Paleo-Tethyan evolution. Comptes Rendus Palevol 10, 1-10.

OKaY, A. I., SATIR, M., TÜYSÜZ, O., AKYÜZ, S. \& ChEN, F. 2001. The tectonics of the Strandja Massif: Variscan and mid-Mesozoic deformation and metamorphism in the northern Aegean. International Journal of Earth Sciences 90, 217-33.

OKAY, A. I., ŞENGÖR, A. M. C. \& GÖRÜR, N. 1994. Kinematic history of the opening of the Black Sea and its effects on the surrounding regions. Geology 22, 267-70.

OKAY, A. I., SUNAL, G., SHERLOCK, S., AltinER, D., TÜYsÜZ, O., KYlander-Clark, A. R. C. \& AYGÜL, M. 2013. Early Cretaceous sedimentation and orogeny on the southern active margin of Eurasia: Central Pontides, Turkey. Tectonics 32, 1247-71.

OKAY, A. I., SUnAL, G., TÜYSÜZ, O., SHERLOCK, S., KESKIN, M. \& KYLANDER-CLARK, A. R. C. 2014. Low-pressure - high-temperature metamorphism during extension in a Jurassic magmatic arc, Central Pontides, Turkey. Journal of Metamorphic Geology 32, 49-69.

OKAY, A. I. \& TÜYSÜZ, O. 1999. Tethyan sutures of northern Turkey. In The Mediterranean Basins: Tertiary Extension Within the Alpine Orogen (eds B. Durand, L. Jolivet, F. Horváth \& M. Séranne), pp. 475-515. Geological Society of London, Special Publication no. 156.

OKAY, A. I., TÜYSÜZ, O., SATIR, M., ÖZKAN-Altiner, S., Altiner, D., Sherlock, S. \& EREN, R. H. 2006. Cretaceous and Triassic subduction-accretion, HP/LT metamorphism and continental growth in the Central Pontides, Turkey. Geological Society of America Bulletin 118, 1247-69.

ÖNDER, F. 1988. Taxonomic features of the Triassic conodonts in the Kayabaşı Formation (in Turkish). Cumhuriyet Üniversitesi Mühendislik Fakültesi Dergisi Seri A 5, 67-90.

PicketT, E. A. \& RoberTson, A. H. F. 2004. Significance of the volcanogenic Nilüfer Unit and related components of the Triassic Karakaya Complex for Tethyan subduction/accretion processes in NW Turkey. Turkish Journal of Earth Sciences 13, 97-144.

ROBERTSON, A. H. F. \& USTAÖMER, T. 2012. Testing alternative tectono-stratigraphic interpretations of the Late Palaeozoic-Early Mesozoic Karakaya complex in NW Turkey: support for an accretionary origin related to northward subduction of Palaeotethys. Turkish Journal of Earth Sciences 21, 961-1007.

ŞAHIN, S. Y., GÜNGÖR, Y., AYSAL, N. \& ÖNGEN, S. 2009. Geochemistry and SHRIMP zircon U-Pb dating of granitoids within the Strandja and İstanbul Zones (NW Turkey). Abstracts, 62nd Geological Congress of Turkey, Ankara, pp. 598-9.

SAYIT, K. \& GÖNCÜOGLU, M. C. 2013. Geodynamic evolution of the Karakaya Mélange Complex, Turkey: a review of geological and petrological constraints. Journal of Geodynamics 65, 56-65.

SEgHEDI, A. 2001. The North Dobrogea orogenic belt (Romania): a review. In Peri-Tethys Memoir 6: Peri-Tethyan Rift/Wrench Basins and Passive Margins (eds P. A. Ziegler, W. Cavazza, A. H. F. Robertson \& S. CrasquinSoleau), pp. 237-57. Mémoires du Muséum National d'Histoire Naturelle de Paris 186.

ŞEnGÖR, A. M. C. 1984. The Cimmeride Orogenic System and the Tectonics of Eurasia. Geological Society of America, Special Paper 195, $82 \mathrm{pp}$.

Somin, M. 2011. Pre-Jurassic basement of the Greater Caucasus: brief overview. Turkish Journal of Earth Sciences 20, 545-610.

Sunal, G., NATAL'In, B., SATIR, M. \& Toraman, E. 2006. Paleozoic magmatic events in the Strandja Masif, NW Turkey. Geodinamica Acta 19, 283-300.

Tari, G., Dicea, O., FAUlKerson, J., GeOrgiev, G., Popov, S., Stefanescu, M. \& WeIR, G. 1997. Cimmerian and Alpine stratigraphy and structural evolution of the Moesian Platform (Romania/Bulgaria). In Regional and Petroleum Geology of the Black Sea and Surrounding Region (ed. A. G. Robinson), pp. 63-90. American Association of Petroleum Geologists Memoir 68.

Tikhomirov, P. L., Chalot-Prat, F. \& Nazarevich, B. P. 2004. Triassic volcanism in the Eastern Fore-Caucasus: evolution and geodynamic interpretation. Tectonophysics 381, 119-42.

Topuz, G., Altherr, R., Siebel, W., Schwartz, W. H., ZACK, T., HASÖZBEK, A., BARTH, B, SATIR, M. \& ŞEN, C. 2010. Carboniferous high-potassium I-type granitoid magmatism in the Eastern Pontides: the Gümüşhane pluton (NE Turkey). Lithos 116, 92-110.

Topuz, G., GöçMengIL, G., Rolland, Y., ÇEliK, Ö., F., ZACK, T. \& SCHMITT, A. K. 2013. Jurassic accretionary complex and ophiolite from northeast Turkey: no evidence for the Cimmerian continental ribbon. Geology 41, 255-8.

Topuz, G., Okay, A. I., Altherr, R., Schwarz, W. H., SunAL, G. \& ALTINKAYNAK, L. In press. Triassic subduction of Paleotethys in northeast Turkey: evidence from the Ağvanis metamorphic rocks. Island Arc.

TÜYsÜZ, O. 1990. Tectonic evolution of a part of the Tethyside orogenic collage: the Karg1 Massif, northern Turkey. Tectonics 9, 141-60.

UĞUZ, M. F., SEvin, M. \& DuRU, M. 2002. Geological Map Series of Turkey, Sinop Sheet, 1: 500 000. Ankara: Maden Tetkik ve Arama Genel Müdürlüğü.

USTAÖMER, P. A., MUNDIL, R. \& RENNE, P. R. 2005. U/Pb and $\mathrm{Pb} / \mathrm{Pb}$ zircon ages for arc-related intrusions of the Bolu Massif (W Pontides, NW Turkey): evidence for Late Precambrian (Cadomian) age. Terra Nova 17, 215-23.

UstaÖmer, T. \& Robertson, A. H. F. 1993. A Late Paleozoic-Early Mesozoic marginal basin along the active southern continental margin of Eurasia: evidence from the Central Pontides (Turkey) and adjacent regions. Geological Journal 28, 219-38.

Ustaömer, T. \& Robertson, A. H. F. 1994. Late Paleozoic marginal basin and subduction-accretion: the 
Paleotethyan Küre Complex, Central Pontides, northern Turkey. Journal of the Geological Society, London 151, 291-305.

USTAÖMER, T. \& RoBerTson, A. H. F. 1999. Geochemical evidence used to test alternative plate tectonic models for the pre-Upper Jurassic (Palaeotethyan) units in the Central Pontides, N Turkey. Geological Journal 34, 2553.

Ustä̈mer, P. A., UstaÖmer, T., Gerdes, A., Robertson, A. H. F. \& Zulauf, G. 2014. Discovery of a Triassic magmatic arc source for the Permo-Triassic Karakaya subduction complex, NW Turkey. Abstracts, 67th Geological Congress of Turkey, pp. 72-3.

Ustä̈Mer, P. A., UstaÖMER, T. \& ROBERTSON, A. H. F. 2012. Ion probe $\mathrm{U}-\mathrm{Pb}$ dating of the Central Sakarya basement: a peri-Gondwana terrane intruded by late Lower Carboniferous subduction/collision-related granitic rocks. Turkish Journal of Earth Sciences 21, 90532.

Wiedmann, J., KozUR, H. \& KaYA, O. 1992. Faunas and age significance of the pre-Jurassic turbidite-olistostrome unit in the western parts of Turkey. Newsletter for Stratigraphy 26, 133-44.

YiĞITBAș, E., ElmAS, A. \& Yilmaz, Y. 1999. Pre-Cenozoic tectono-stratigraphic components of the Western Pontides and their geological evolution. Geological Journal 34, 55-74.
YILMAZ, İ. 1975. Determination de l'age d'un granite de Sancaktepe, dans la presquile de Kocaeli (Nord de la Mer de Marmara). Comptes Rendus Académie des Sciences D 281, 1563-5.

YILMAZ, O. \& BozTUĞ, D. 1986. Kastamonu granitoid belt of northern Turkey: first arc plutonism product related to the subduction of the Paleo-Tethys. Geology 14, 179-83.

YILMAZ, O. \& BOZTUĞ, D. 1987. Geological and mineralogical-petrological investigation of the Göynükdağı (Kastamonu) region. Doğa Türkiye Mühendislik ve Çevre Dergisi 11, 91-114 (in Turkish).

YILMAZ, Y. \& ŞENGÖR, A. M. C. 1985. Palaeo-Tethyan ophiolites in northern Turkey: petrology and tectonic setting. Ofioliti 10, 485-504.

Yilmaz, Y., TÜYsÜZ, O., YIĞITBAŞ, E., CAN Genç, Ş. \& ŞENGÖR, A. M. C. 1997. Geology and tectonic evolution of the Pontides. In Regional and Petroleum Geology of the Black Sea and Surrounding Region (ed. A. G. Robinson), pp. 183-226. American Association of Petroleum Geologists Memoir 68.

YURTTAŞ-ÖZZDEMIR, Ü. 1971. Macrofauna and biostratigraphy of the Tepeköy Triassic on the Kocaeli peninsula (in Turkish). Maden Tetkik ve Arama Enstitüsü Dergisi 77, 57-98.

ZONENSHAIN, L. P., KuZMin, M. I. \& NATAPOV, L. M. 1990. Geology of the USSR: A Plate Tectonic Synthesis. Washington, DC: American Geophysical Union, 242 pp. 